\title{
Through the Eyes of a Mapmaker: Maritime Shrines on Cyprus during the Late Middle Ages
}

\author{
Ourania Perdiki
}

Citation: Perdiki, Ourania. 2021

Through the Eyes of a Mapmaker:

Maritime Shrines on Cyprus during the Late Middle Ages. Religions 12: 1022. https://doi.org/10.3390/ rel12111022

Academic Editors: Giorgos

Papantoniou, Athanasios K. Vionis and Christine E. Morris

Received: 30 September 2021 Accepted: 16 November 2021 Published: 21 November 2021

Publisher's Note: MDPI stays neutral with regard to jurisdictional claims in published maps and institutional affiliations.

Copyright: (c) 2021 by the author Licensee MDPI, Basel, Switzerland. This article is an open access article distributed under the terms and conditions of the Creative Commons Attribution (CC BY) license (https:// creativecommons.org/licenses/by/ $4.0 /)$.
Archaeological Research Unit, University of Cyprus, Nicosia 1678, Cyprus; perdiki.ourania@ucy.ac.cy

\begin{abstract}
Cyprus acquired special importance, especially from the thirteenth century onwards, on the Eastern Mediterranean's pilgrimage network. Described by contemporary pilgrims as “Terra christianorum ultima", the island was considered to be the last Christian land in the south-eastern Mediterranean on the pilgrims' itinerary on their journey to the Holy Land. This study is concentrated on two maps of Cyprus dated to the fourteenth century and preserved in Milan: Biblioteca Ambrosiana, A95 sup. and Venice: Biblioteca Nazionale Marciana, gr. XI.21. It aims to explore the physical and spiritual mobility and interconnectivity in Cyprus during the late Middle Ages and to consider how these contribute to the development of pilgrimage sites directly related with maritime routes, seamen and travellers. These unique nautical maps captured the sea voyage which had Cyprus as a stopover, bringing to light new insights into fourteenth century Cyprus. The maritime shrines discussed in this article, which are usually "mixed" sacred sites, are directly related with sailors' needs. They integrate into a wide network of communication, removing them partially from their local dimension.
\end{abstract}

Keywords: Cyprus; late Middle Ages; pilgrimage; map of Cyprus; medieval cartography; history of navigation; maritime shrine; connectivity; mixed shrines; maritime routes

\section{Introduction}

Cyprus, as the third largest island in the Mediterranean, represents an ideal study domain with clearly defined geographical boundaries, where blended cultures and different religious groups have been presented diachronically, from the prehistoric years to the most recent past. Thus, being defined and at the same time confined by the sea, communities on the island tended to interact with one another and with the outside world (cf. Hadjikyriakou 2017).

The intense commercial activity observed on the island and the economic prosperity to which it led, together with its strategic position close to Asia Minor, the Syropalestinian and the Egyptian coasts, rendered Cyprus the battleground between Byzantines, Arabs, Crusaders, Venetians, and Ottomans on several occasions. Cyprus, being the easternmost Christian land of the Mediterranean in the late Middle Ages, constituted a border between West and East. Therefore, the geographical position of the island at the crossroads of three continents (Europe, Asia, Africa) and par consequence, a passage for traders, pilgrims, and conquerors, diachronically played a role in the formation of its history.

This article aims to re-examine two maps of Cyprus dating to the fourteenth century, preserved in two manuscripts that contain medical treatises, i.e., Milan: Biblioteca Ambrosiana, A95 sup.; Venice: Biblioteca Nazionale Marciana, gr. XI.21. By reinterpreting these maps as reflections of a navigational map rather than as personal creations, we will draw upon a range of disciplinary approaches to show how Cyprus' extensive maritime interconnectivity interacted with and contributed to the development of pilgrimages to the island during the late Middle Ages. 


\section{Cyprus as a Pilgrimage Centre during the Late Middle Ages}

In general, the launch of Christian pilgrimage can be placed at the beginning of the fourth century (Maraval 1985). After the well-known religious journey of St. Helen (326 A.D.), mother of Constantine the Great, to Jerusalem, a myriad of Christian pilgrims from all over "New Rome" set out to walk in her footsteps. The pilgrimage to the sites of the Christ's birth, life and passion was motivated by sincere spiritual longing and led to the hope of attaining salvation in the afterlife. Although the conquest of the Holy Land by the Arabs in the seventh century made pilgrimage to the loca sancta of Palestine and Egypt a much more difficult and dangerous proposition, Christians continued to make the journey from Western Europe and the lands of the Byzantine empire.

Cyprus has a long tradition of creating sacred spaces, from the late Bronze Age (ca. 1700-1125/1100 B.C.) until today (Papantoniou 2012; Papantoniou 2016). Indeed, the island was also one of the first lands outside the Holy Land and Palestine to adopt Christianity, long before it was attested in Athens, Rome, or Alexandria. The new religion spread throughout the island during the first mission of the apostles Paul, Barnabas, and Mark-the latter of Cypriot descent-in 45 A.D. (Acts of the Apostles 13: 4-12). Despite the early Christianisation of the island's population, it was only in the fourth century that Cyprus acquired the institutional apparatus of Christianity, with several prominent bishops (cf. Deligiannakis 2018a, 2018b). Over the centuries, Christianity was strongly consolidated in the island. The well organised, autocephalous, local Church and its geographical position in the eastern corner of the Mediterranean and close to the Holy Land, constituted two of the main reasons for the development of a large number of pilgrimage sites on the island, which were shared by the Christian population. The fame of its saints and holy places has attracted over the centuries-and in some cases still attracts-many pilgrims via the maritime route. It is worth mentioning that one of the first pilgrims who visited the island to venerate its monasteries and shrines was St. Paul of Rome (347-404 A.D.), student of St. Jerome, who visited Cyprus in 385 A.D. and stayed there for ten days (Maraval 1996, p. 147).

Nevertheless, pilgrimage to the Holy Land seemed to flourish at the beginning of the second millennium, following heightened religious fervour (Jacoby 2016). A severe blow to overland pilgrimage occurred in 1071 with the Seljuk victory over the Byzantines at the Battle of Manzikert and the subsequent occupation of much of Asia Minor by the Seljuks. The Seljuk conquest of that part of Anatolia, through which ran the pilgrims' road, was certainly a catalyst for the First Crusade (1096-99) which intended to make pilgrimage safer by asserting Christian control over the loca sancta and the main routes to and within the Holy Land. Indeed, the number of pilgrims increased after 1099 and a crowd of people, from all social and economic layers, undertook the journey to the Holy Land by taking either the terrestrial or the maritime route. This journey had a direct impact in Cyprus, as pilgrims stopped in Cyprus en route to Jerusalem for supplies. During this period, Cyprus had developed and promoted its own shrines in order to benefit from the crowds of travellers-pilgrims stopping over on the island. Therefore, the island became part of the whole journey. Not surprisingly, the majority of pilgrimage sites and monuments in Cyprus belonged to the Greek community. Pilgrimage sites and other sacred places in Cyprus consisted of shrines with healing relics, sacred springs, miraculous icons, and objects, as well as places such as caves, in which holy men lived (cf. Simsky 2020). Undoubtedly, pilgrimage sites were places of high religious, political, and economic importance in the Middle Ages (cf. Vionis and Papantoniou 2019, pp. 10-13). In several cases, they still maintain their importance today.

Cyprus acquired special importance, especially from the thirteenth century onwards, due to the conquest of Syria and Palestine by the Mamluks. As mentioned earlier, the island was the last Christian land in the south-eastern Mediterranean for pilgrims' itinerary to the Holy Land. The German priest Ludolf of Sundheim, who visited Cyprus between 1336-41 during his journey to the Holy Land, had rightly described Cyprus as "Terra christianorum ultima" (Deycks 1851, p. 34; Burkiewicz 2018, p. 209). Moreover, it was an ideal base for 
controlling the Muslim Middle East and the transit trade between Europe, Asia, and North Africa (Balard 1993, pp. 271-82, esp. 276).

During the late Middle Ages, the journey to Jerusalem became more intense and more organised and Venice and Cyprus had a remarkable position within it (cf. Vingopoulou 2003). Venice was deeply involved in and monopolised the pilgrim traffic; it was the port of embarkation for pilgrimage to the Holy Land from Northern Italy and from countries beyond the Alps (Jacoby 2016, pp. 89-97). This sea journey from Venice to Jaffa was expensive, difficult, and dangerous and many of the travellers died during the trip. The travellers, before the departure, signed a contract with all the terms and conditions of the journey (duration, stopovers, food supplying etc.). The duration of the journey from the West varied depending on weather conditions. It took place mainly from April to October and it took approximately forty days during the fifteenth century (Grivaud 1990, pp. 19-25); the journey lasted twenty-seven days between May and June and Cyprus-Jerusalem lasted only three days.

The travellers who stopped in Cyprus were humanly diverse with correspondingly varied economic capabilities. They usually stopped for fifteen to twenty days in Cyprus and, depending on their interests and curiosity, visited different sites, monasteries, and pilgrimage sites on the island. The travellers who arrived in Cyprus can be divided into three main categories (Grivaud 1990, pp. 11-18). The first group consisted of pious Christian pilgrims (mainly priests and abbots belonging to various western religious orders) who occasionally travelled to the Holy Land; the second one concerned traders travelling for financial profit and the third group included travellers who visited Cyprus for different reasons such as espionage and adventurism. It is interesting that no women are documented as visiting Cyprus in this period. The travellers usually recorded their travel experiences in diaries which give us valuable information about the pilgrimage sites; sometimes they provide the only surviving evidence for some shrines. However, the researcher faces several problems when examining travellers' reports, such as the reliability of these documents, the truth of recorded information, their intentions, and their personal assumptions.

\section{The Two Maps of Cyprus of the Fourteenth Century}

Two schematically drawn, freehand maps of Cyprus, rare and unique in the Byzantine world, are preserved: the first one in Milan: Biblioteca Ambrosiana, A95 sup., dated to the early fourteenth century, and its copy in Venice: Biblioteca Nazionale Marciana, gr. XI.21 (coll. 453), executed in the middle of the fourteenth century. The two maps were first published by Cronier and Gautier Dalché (2017), and then discussed by Toumpouri (2018). Both maps are preserved in two Greek medical manuscripts which contain various therapeutic recipes and treatises.

\subsection{The Ambrosiana Map}

The scribe and owner of the manuscript was a physician who copied it for his own use, as the annotations added day by day demonstrate (Cronier and Gautier Dalché 2017, p. 177; Cronier 2020, pp. 131-36). It is important to state that the person who drew the map and added the inscription above it was not necessarily the person who created the manuscript (see below; Figure 1). Based on the marginal notes, the manuscript was produced in Constantinople; then, it was transferred to the emirate of Menteşe in southwestern Asia Minor, as its owner had been asked to cure the son of Selman Paşa, a Turkish ruler of the Menteşoğlu dynasty (in the 1330s). Finally, the manuscript arrived in Cyprus (mid-fourteenth century) (Cronier and Gautier Dalché 2017, pp. 177-78). 


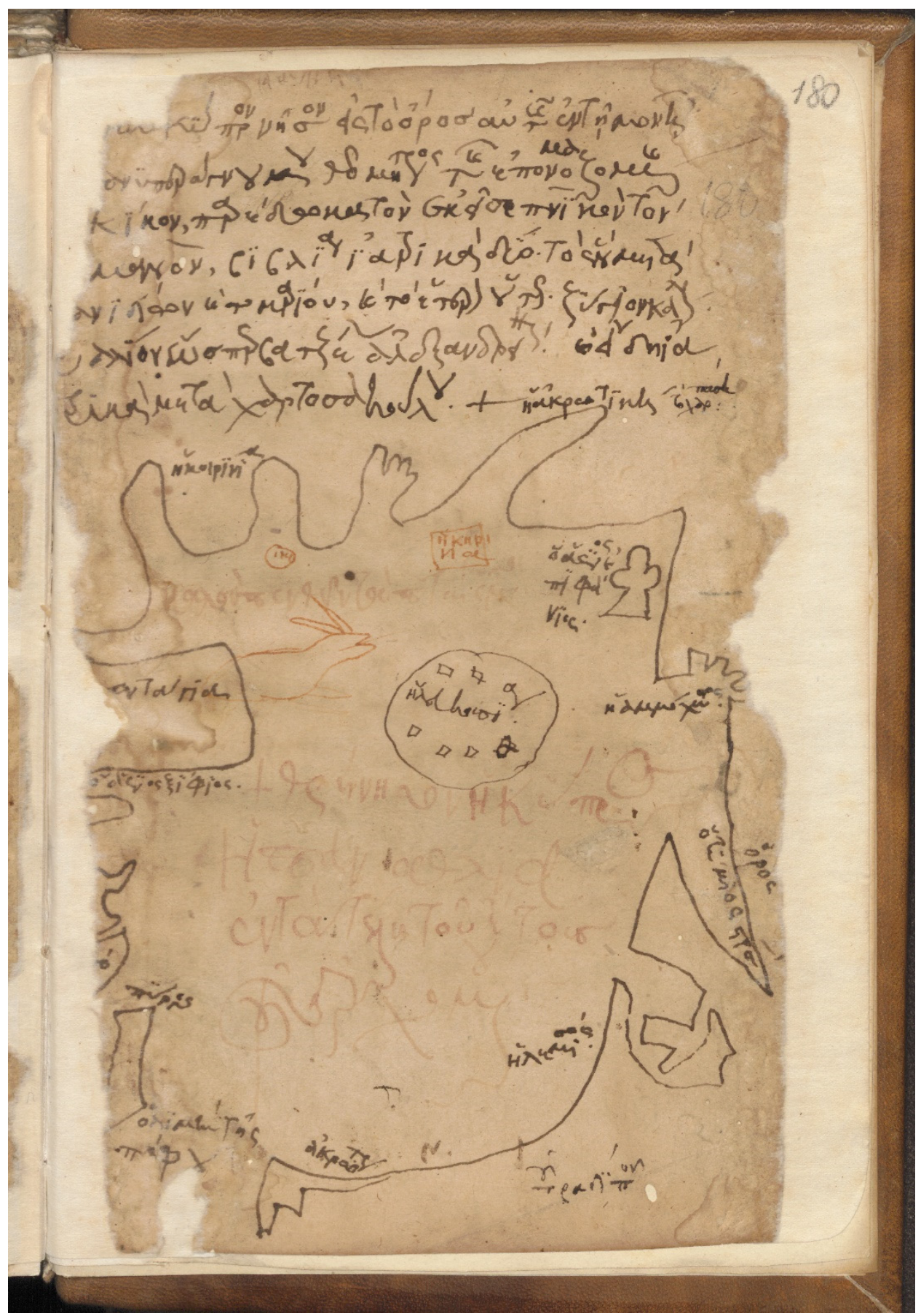

Figure 1. The Ambrosiana map of Cyprus. Milan, Ambrosiana MS A95 sup., f. 180r. First half of the fourteenth century (Reproduced with permission from the Veneranda Biblioteca Ambrosiana, Milan).

The map of Cyprus constitutes one of the last additions to the manuscript. It was drawn on the last page (f. 180r), which was probably originally a blank leaf. According to Cronier and Gautier Dalché, the epigram and the sketch of the rabbit were added first, and the map was later drawn around it (Cronier and Gautier Dalché 2017, p. 178). However, we observe that the rabbit and the place-name "Kyrenia" are written in the same red ink (see below). As the placename can only be explained by the presence of the map and as the epigram was fully enclosed within the map, written in pale orange ink, we can suppose that they are all additions to the page after the map was drawn there. The epigram 
was written by a different hand from that which wrote the note above the map and the map's toponyms:

$\mathrm{K} \alpha \lambda \grave{\nu} v \pi \varepsilon v \theta \varepsilon \tilde{\imath} v \tau \grave{\alpha} \pi \tau \alpha \dot{i} \sigma \mu \alpha(\tau \alpha) \mu \mathrm{ov}$

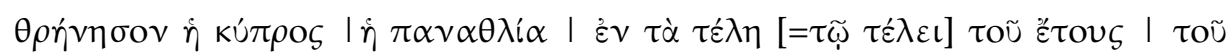

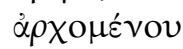

It is good to bewail my sins/Wail, Cyprus, you all-wretched, at the end of the year that begins. (The transcription and translation are of Cronier and Gautier Dalché 2017, p. 178)

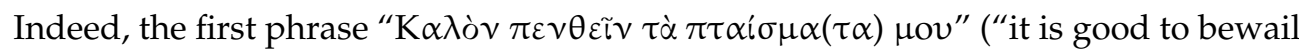
my sins") indicates a man who was pious with religious zeal. In addition, the epigram refers to an uncertain misfortune that hit Cyprus. If we accept that the manuscript was in Cyprus in the mid-fourteenth century, it may be implying the Black Death of 1347-48, which hit Cyprus as hard as it had hit most other areas of Europe and the Mediterranean (cf. Papacostas 2018), reducing the population of the island by between one third and one fifth. Moreover, a Turkish attack on the fortress at Kyrenia in December 1347 is attested due to the island's vulnerable coastline (Papacostas 2018, p. 137). Furthermore, the severe outbreak of Black Death of c.1361-63 was accompanied by Turkish raids on the north coast. According to Leontios Makhairas, the Cypriot chronicler, writing between 1426-32, the Turks were facilitated by the fact that the island was empty and defenceless (Dawkins 1932, §135, §137; Papacostas 2018, p. 137).

The person who drew the map chose to mark mainly coastal sites or places directly related with sea. Therefore, sixteen name-places are recorded. Among them two important shrines and only two sites are cited inland (Nicosia and Kyrenia). Thus, we can

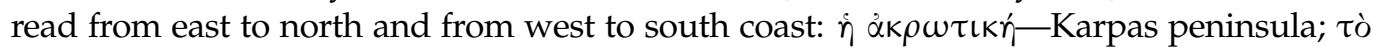

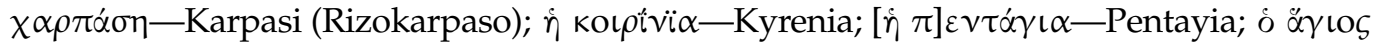

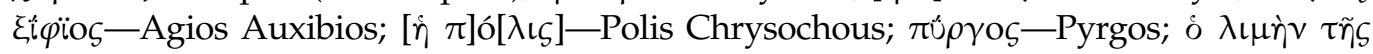

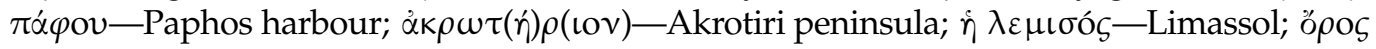

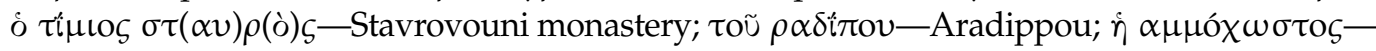

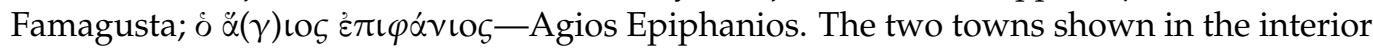
are $\dot{\eta} \kappa \eta \rho \iota v \iota \alpha$-Kyrenia and $\dot{\eta} \lambda \varepsilon \mathcal{v} \kappa o v \sigma i \alpha$-Nicosia.

Concerning the toponyms, $\dot{\eta} \dot{\alpha} \kappa \rho \omega \tau \iota \kappa \dot{\eta}$ can be identified with the Karpas peninsula and can be associated with the ancient Greek temple of Aphrodite Akrea, located at the north-eastern end of the peninsula. The epithet "Akrea" refers to something that it is located on the edge; the toponym "Akrotiki" seems to arise from this epithet "Akrea-Akrotiki". The name "Akrotiki" is attested firstly in Leontios Makhairas (Dawkins 1932, §34, §191, $\S 448, \S 654)$. Based on his writing, it is not easy to determine which part of Karpas is implied. Depending on the text context, the name Akrotiki sometimes seems to be situated near the village Agios Andronikos, sometimes at the anchorage Helones (Turtles), which is located between Rizokarpaso and Cape Apostolos Andreas, and sometimes it seems to refer to the area north of Famagusta. The toponym is also preserved in the bilingual text (Italian-Greek) of the "Regulations of Karpas Peninsula Territory", dated to the 1563 and preserved in the Venetian State Archives. The Italian text noted "Volendo il magnifico Misser Francesco Calergi honoratissimo Balio del Carpasso regger questa contrada." and its

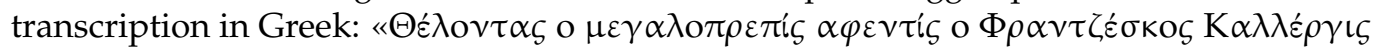

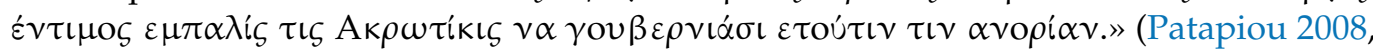
p. 27; Patapiou 2015). Based on the above-mentioned document, the name-place, Akrotiki, can surely be identified with the whole peninsula of Karpas.

Moreover, $\tau o ̀ ~ \chi \alpha \rho \pi \dot{\alpha} \sigma \eta$ refers to the village called Rizokarpaso. The village Karpasi is also observed in medieval written sources; it is known as "casal du Carpas" in Frankish documents and as "casal del Carpasso" in Venetian ones (Patapiou 2015). The name "Risocarpaso" (Rizokarpaso) seems to appear for the first time in the map of Leonidas Attar, dated to 1542 (Cavazzana and Grivaud 2006, p. 97). 
Two sites labelled as "Kyrenia" are marked on the map situated not far from each other. The first one is the coastal city and harbour ( $\dot{\eta} \kappa \circ \iota \rho$ i $\ddot{\imath} \alpha)$ and the second one $(\dot{\eta} \kappa \eta \rho \iota v \iota \alpha)$ is located inland and above the city of Nicosia. For the moment, it is difficult to suggest an interpretation concerning the second toponym. However, it is interesting to mention that the second Kyrenia was added later and although the hand is similar, it was written with a different red ink (see above). This was probably a mistake or a misunderstanding of the toponym.

Furthermore, Pyrgos is situated at the west coast of the island and probably corresponds to the tower known by the name of Pyrgos tis Rigainas at the Akamas peninsula (Jeffrey 1983, p. 412; Wallace 1984, pp. 346-47 and Figure 1; Fejfer 1995, p. 60). In Attar's map of 1542, the tower is cited as "Merovigli" (Cavazzana and Grivaud 2006, pp. 46-47, Figure 30a). The scope of this type of tower was not to protect rural populations; according to medieval tradition, it must have been part of the watch system and it was established by the Byzantines during the rule of Constantine the Great (Dawkins 1932, §6; Cavazzana and Grivaud 2006, pp. 46-47). The different watch towers of the island communicated by means of signals, as Stefano Lusignan noted in the late sixteenth century (De Lusignan 1580, f. 218r).

At a later time, and outside the map's coastline frame, Aradippou ( $\tau$ ũ $\rho \alpha \delta$ i் $\pi$ ou) was

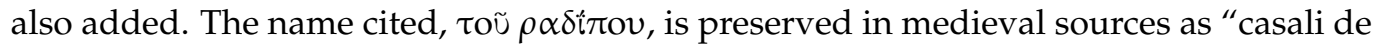
Radipe" (Grivaud 2008, p. 363). Aradippou is associated with King Hugh IV (1324-58), who had a manor house there which he visited every spring. We know that he resided in his manor during the month of March in 1352, 1353 and 1354 (Grivaud 2008, p. 363). The insertion of Aradippou on the map is not entirely surprising; Aradippou was an important village of the area due to the royal manor. The anonymous draughtsman of the map may have added the village after hearing something about it.

It is possible that the person who drew the map arrived in Cyprus at Paphos' port, as it is the only place-name cited as a port ( $\dot{\delta} \lambda \iota \mu \dot{\eta} v \tau \tilde{\eta} s \tau \dot{\alpha} \varphi \mathrm{ov})$. Travellers arriving from the Aegean and Asia Minor usually anchored at Paphos' port. Although Kyrenia, Limassol and Famagusta were also ports - the latter had become the major harbour on the island during late Middle Ages-they were not labelled as such. However, the map drawer, by using iconographic signs, had stated that all these places were ports, i.e., the coastline is shown with projections on the coast.

The peninsula of Akrotiri ( $\dot{\alpha} \kappa \rho \omega \tau \dot{\eta} \rho\llcorner\mathrm{v})$ was also an anchorage, as the delineation on the map indicates. Throughout the centuries, travellers, pilgrims, and refuges arrived from the opposite coast, especially from Alexandria. Akrotiri was famous for its salt lake, which was a major resource to the royal court during the Lusignan period; although, Larnaca's salt was of better quality and was therefore sold at higher price (Nicolaou-Konnari and Schabel 2015, p. 216).

Pentayia is located at the north coast, near the area of Soloi. The name "Pentayia"

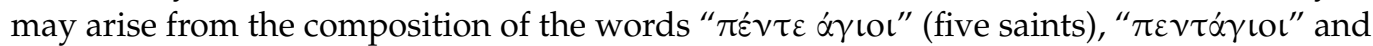
" $\pi \varepsilon \nu \tau \alpha \dot{\gamma} \gamma \varepsilon \iota \alpha$ " (Jeffrey 1983, p. 224). The village seems to have gained great prosperity during the Lusignan period. It was the administrative centre of the district and one of the twelve baronies of the Kingdom of Cyprus; according to Mas Latrie, it was a royal estate (Mas Latrie 1970, p. 528). The village is also observed in medieval sources; Leontios Makhairas refers to it six different times (Dawkins 1932, §137, §377, §427, §444, §447, §613). The mapmaker may indicate the large bay of Pentayia and not the village; the name is written outside the coastline-frame of the map and within the schematic line which forms the bay. The ships from Asia Minor usually stopped at this bay.

The toponym $\delta \propto \alpha \gamma \operatorname{lo\zeta } \xi \ddot{\imath} \varphi \ddot{i} \sigma s$ is located in Pentayia bay. It probably refers to the small port of Agios Efxifios at Soloi and not to the episcopal basilica of Agios Auxibios. Makhairas cites the port of Agios Efxifios ('A $\gamma \operatorname{lo\zeta }$ Ev $\xi \varphi \eta \zeta)$ three times in relation to the Genoese invasion of Cyprus (1373) and the treaty between the Kingdom of Cyprus and the Republic of Genoa signed in 1383 or 1385 (Dawkins 1932, §377 and §613). According to this treaty, the Genoese ships would anchor only in Famagusta and not in other Cypriot 
ports whose names are mentioned; among them Agios Efxifios. Moreover, the chronicler noted that Helen Palaiologina, who married the King of Cyprus, John II (1432-58), arrived in Cyprus on 2 February 1442 and disembarked at Agios Efxifios (Dawkins 1932, §709). The identification with the episcopal basilica of Agios Auxibios, who was the first bishop of Soloi, seems doubtful. The cult of Agios Auxibios seems to have existed more as a local than as a long-distance pilgrimage destination. According to an archaeological excavation, which is still unfinished, the presence of a smaller core of the saint's cult seems to exist from the twelfth to the fifteenth century (Nicolaou 2017, p. 83).

Stravrovouni Monastery, or the Mountain of the Holy Cross as it is cited as on the map, was by far the most famous pilgrimage destination for pilgrims, both local and foreign. The monastery stands on the prominent isolated peak ( $688 \mathrm{~m}$ above sea level) called Mount Olympus, near Pyrga village in the district of Larnaca. Its privileged position is also emphasised on the Ambrosiana map; it is indicated by a pointed triangle protruding towards the sea. Its strategic position between Nicosia, Limassol and Larnaca, with a clear view to the south coast of the island, the Mesaoria valley and the Troodos mountains, was often described by pilgrims and travellers.

According to Cypriot tradition, the monastery was founded by St. Helen around 32729 A.D. On her return journey from Palestine, she left a piece of the cross of the penitent thief and built a small chapel to house it. The Russian monk, Daniel (1106,) first reported Stavrovouni's association with the legend of St. Helen (Garzaniti 1991, p. 80). During the late Middle Ages, this tradition was still alive; Ludolf of Sudheim noted it in the 1330s (Cobham 1908, p. 19) and Leontios Makhairas described St. Helen's journey to Cyprus in detail in the fifteenth century (Dawkins 1932, §8). Nevertheless, there is no archaeological evidence to support the legend of St. Helen. Megaw has cited that the earliest architectural phase of the monastery is the triconch sanctuary with a groin vault over the altar (Megaw 1974, p. 61 n.14).

After its foundation, Stavrovouni was occupied by Orthodox monks. The Greek clergy was replaced by the Black Monks, Benedictines from Antioch, around 1240 or 1246 . Almost all the pilgrims of the thirteenth and fourteenth century comment on the Benedictine monastery with the Black Monks and the "cross of the good thief", which became a "topos". The pilgrimage was probably reinforced by the addition of a series of relics during the fourteenth century, as pilgrims inform us (Cobham 1908, pp. 16, 27, 29, 40). It seems that Stavrovouni was a much-visited pilgrimage goal for fourteenth century travellers; one hundred thousand pilgrims had seen the cross according to Guillaume de Machaut's estimation (1365-Shirley 2001, p. 24). Needless to say, the pilgrimage trade was not affected by the different inhabitants who had the monastery under their domination.

In addition to the cross, and the various relics housed in the monastery, the miracle of the suspended cross was also a major attraction. This miracle was already noted from the early twelve century; the cross was suspended in the air without visible attachment and shook (Cobham 1908, pp. 18, 27, 28, 40; Garzaniti 1991, p. 80). Information about the pilgrimage object is unclear and uncertain. As Makhairas and an Arab chronicler mention, the monastery was destroyed and looted by the Mamluks during the 1426 invasion (Dawkins 1932, §695; Mansouri 2001, p. 129). Moreover, an Arab source informs us that the cross was taken by the Mamluks and that they discovered that it was suspended by springs, which explains its shaking. Nevertheless, some years later, the cross re-emerges in the pilgrims' notes; Felix Faber recorded in 1483 that he saw the cross and he describes it in detail (Cobham 1908, p. 40). We can assume that the Mamluks may have not taken the large cross, but probably one other cross, or they may have returned it later to the monastery.

The association of Stavrouvouni with the trade routes and sailors of this period is obvious. Ludolf of Sudheim (1330s) noted that the monastery was saluted by seamen, underlining its role as a major navigational landmark; its peak was visible even in bad weather (Cobham 1908, p. 19). Moreover, according to James of Verona (1346), who visited the monastery on his way back to Famagusta from Nicosia, it was particularly venerated by sailors (Cobham 1908, p. 18). For all those who travelled the seas, merchants, pilgrims and 
ship crews, the reminder of the presence of a sacred place, such as a church or a monastery, was a vital comfort. Through these sacred establishments, travellers could pray to the saint to whom the church was dedicated and ask for the protection of the housed sacred relics. If the travellers landed nearby, they had to visit and pray to thank the saint for allowing them to survive sea dangers.

Ambrosiana's map also singles out the basilica of Agios Epiphanios, bishop of Constantia (367-403), situated in the area of ancient Salamis (eight kilometres north of Famagusta city). The basilica of Agios Epiphanios is one of the earliest monuments of Christianity in Cyprus and its construction began during the last years of the episcopacy of Epiphanios (cf. Foulias 2019, pp. 719-29). St. Epiphanios was buried in 403 and venerated at his shrines throughout the late antique to medieval period. The draughtsman of the map drew the basilica as a trefoil, evoking the three-aisled barrel-vaulted church with three domes that had been constructed in the eighth century and survived still in the mid-fourteenth century when it was associated with the cult of St. Catherine (cf. Calvelli 2009, pp. 157-245). The citation of the basilica on the map may testify that the saint's relic was still attested there, for we know his cult was alive between 1345-49 (Hoade 1970, p. 60). Their presence at the basilica in Salamis is also stated by contemporary travellers (see above and Cobham 1908, p. 20). Leontios Makhairas informs us those parts of his relics were circulated within the island during the fourteenth century. Indeed, after the miracle in Tochni (1340), Patriarch Ignatios of Antioch included one of Epiphanios' relics among the many in the great cross he made in order to be used in processions around the new church against locusts, drought, or plague (Dawkins 1932, §77). Moreover, Epiphanios' skull was venerated in the Latin cathedral of Nicosia, where a commemoration was instituted in 1357 (Coureas and Schabel 1997, p. 310; Schabel 2001, p. 366). In the sixteenth century, part of his relics was possibly transferred to Famagusta to the church dedicated to Agios Symeon or to Agios Epiphanios which adjoined the large cathedral of Agios Georgios ton Ellinon (St. George of the Greeks) (Kaffenberger 2014, pp. 171-80; Papacostas 2014, pp. 46-50).

We return to the manuscript; above the map a note in seven lines is added, plausibly by the same hand who drew the map. The hand is similar but not identical to the copyist of the main text of the manuscript (Cronier and Gautier Dalché 2017, p. 178). It is possible that the man who wrote the note and executed the map was the copyist himself, but at an older age.

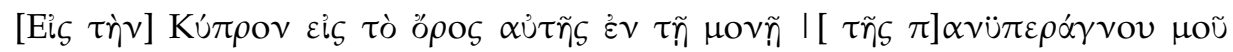

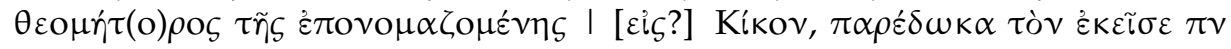

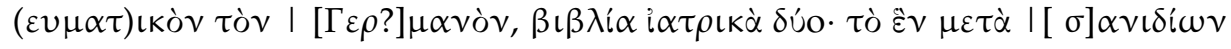

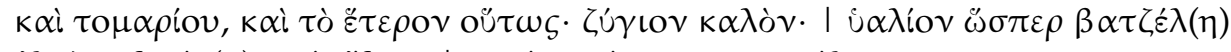

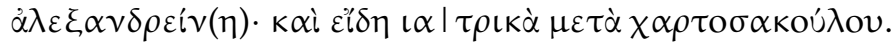

In Cyprus, upon its mountain, in the monastery of the All-Saint Mother of God called [at?] Kykkos, I gave to the spiritual father [Ger]manos, two medicine's books; the one with wooden boards covered with leather, and the other too; good scales; a glass jar, like the Alexandrian vessel; and medical utensils, with a paper bag (The transcription and translation are of Cronier and Gautier Dalché 2017, p. 178).

The note informs us about a transaction with the Monastery of the Virgin of Kykkos in Cyprus (Figure 2). The anonymous man gave two medical manuscripts and other medical materials (scales for weighting ingredients, a transparent glass jar, and a bag with small medical implements) to the monk of the monastery, Germanos, who was also a "pneumatikos" (spiritual father). The monk was probably a physician. The person who gives this medical equipment was probably a doctor and could have been the original maker of the manuscript. However, we have no evidence to declare that he was the same physician who made the book. 


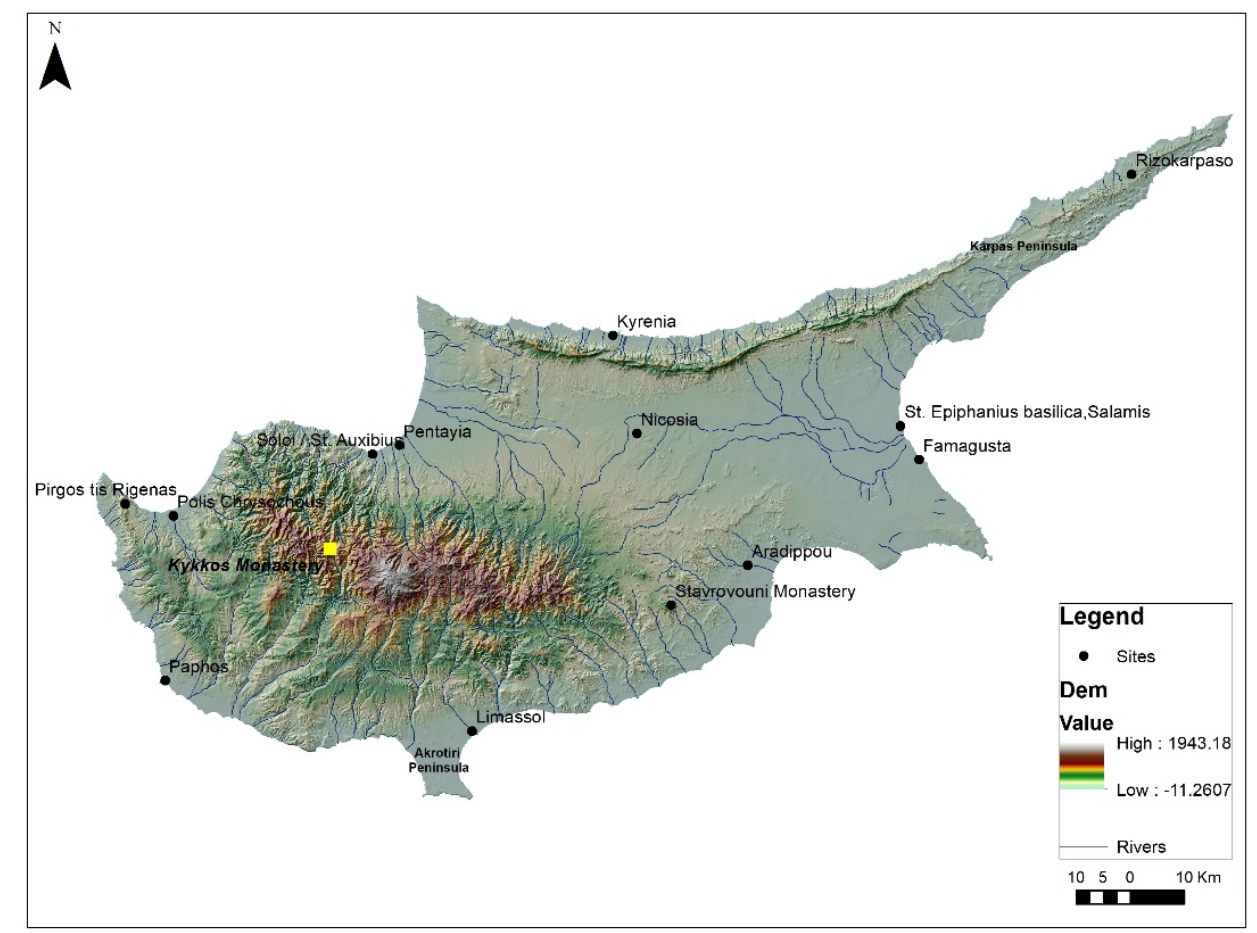

Figure 2. Map of Cyprus with toponyms and sites cited in Ambrosiana Map (Map by Niki Kyriacou).

Based on the information at our disposal, we can assume that the initial owner of the manuscript was from Constantinople (Cronier 2020, p. 132). This man was probably a well-known physician as he had been asked to give his medical services to the son of a ruler at Menteşe (Cronier 2020, pp. 133-34). After Asia Minor, the manuscript continued its journey to Cyprus. As mentioned above, we do not know if the original scribe of the book was the same person who possessed the manuscript in Cyprus. Although previous studies (Cronier and Gautier Dalché 2017, p. 180) have presumed that the person who owned the manuscript in Cyprus created this unique map, drawing it free-hand as his own work, we can raise the hypothesis that the Ambrosiana map was probably inspired by a sailing chart and it does not record a personal journey. The anonymous man may have found the map on the ship during his journey to Cyprus and he may have copied it. This type of map, the later so-called portolan, was taken to sea and was regarded as a practical aid for navigation, perhaps with the help of dividers. Moreover, they may have served mostly as a simple aide-mémoire, a handy guide to the features of coasts (Harvey 1991, p. 45). Our map seems to be based on a chart of Cyprus, used in navigation as it emphasised the coastal line of the island. The many coastal place-names cited on the map are mainly written on the land side of the coastline as not to obscure possible danger points. The Ambrosiana map also presents some navigational landmarks such as Stavrovouni Monastery and only one inland feature is shown; as mentioned, only the capital city of the island. Tony Campbell has stated about maritime maps: "the names, written inland and at right angles to the coast, run in a continuous sequence which presents some 'upside down', whichever way the cart is turned" (Campbell 1984, p. 48). All the above-mentioned features are observed both on sailing charts and on the Ambrosiana map (cf. Harvey 1991, pp. 39-49). However, our map drawer chose not to copy the so-called rhumb lines that usually cover the portolan maps. If our hypothesis is correct, the Ambrosiana map reflects how the nautical community in general saw the island in the late Middle Ages. Certainly, our map was drawn as a copy and never meant to be taken to sea. Moreover, it is interesting to note that each place that is marked on the map has pilgrimage significance (cf. Section 4 of this article). Nevertheless, the question arises as to why the anonymous man copied the map. Perhaps, he was a multifaceted personality with travelling interests. It is also possible that the anonymous man was planning to visit the Holy Land as a pilgrim 
and made a stopover to the island. However, there is insufficient evidence to confirm this suggestion. The iconographic symbols used for Agios Epiphanios (trefoil referring to the three-domed basilica), and Nicosia (circle with six small squares implying the medieval city walls), were perhaps copied from the initial map. However, it is still unknown if he visited these places and then added the icons. Certainly, the anonymous man had various interests and curiosities (physician, draughtsman of a map, pilgrim?) and so it would seem that he was by no means an ordinary medieval man. This observation gives us more details about the travellers arriving in Cyprus during the late Middle Ages.

Concerning Kykkos Monastery, the following questions arise: When did the anonymous man become informed about Kykkos Monastery? Did he visit Kykkos as a pilgrim? Was it there that he met Germanos, or did Germanos himself invite him to the monastery? It is worth mentioning that Kykkos may have not been a well-known monastery; it was a monastic establishment in the Troodos mountains with a regional impact. Thus, it is possible that the physician learned about Kykkos on the boat or when he arrived at Paphos and that he probably went to Kykkos as a pilgrim. During his visit, he met Germanos and he gave medical books to the monastery as well as other medical materials. We suppose that all these things were sold or exchanged with something else as the verb " $\pi \alpha \rho \varepsilon \delta \omega \kappa \alpha$ " $(\pi \alpha \rho \alpha \delta i \delta \omega \mu l)$ means "give", "hand over to another", "transmit". If it was a donation, we suppose that he would have specified this. If the above-mentioned hypothesis is correct, then Germanos or the monastic community of Kykkos must have had some financial capacity. There can be no doubt that the Ambrosiana manuscript was one of the two books that the anonymous man had given to Germanos and that he wrote this note above the map as a reminder of the affair. It is difficult to determine the exact time period when this action took place. It is worth remembering that in June 1365, Kykkos was destroyed by a fire that broke out near the monastery. The monastery was rebuilt by December that same year, thanks to the donation of Eleanor, the wife of King Peter I (1359-69) (cf. Roudometof and Michael 2010, p. 58). Thus, this transaction should have taken place either before the fire, as we do not know its extent, or after that. It is more likely that this event took place after the fire because in this fire, all the books of Kykkos were probably burned, which led the monk Gregorios to write a new description of Kykkos monastery.

\subsection{The Marciana Map}

The Marciana manuscript was probably copied in Cyprus; the type of paper used for the manuscript is oriental paper, which was very common on the island in the midfourteenth century (Cronier and Gautier Dalché 2017, p. 180). The Marciana manuscript reproduces the Ambrosiana manuscript closely. In particular, the map is copied on the last page of the manuscript (f. 166v) and presents some changes (Figure 3). The city of Kyrenia appears only once; the copyist marked only the correct coastal city. The villages of Aradippou and Karpasi have disappeared. Moreover, all the other notes (epigram and text above the map) are not copied. The two villages were placed quite far from the coastal frame-line determining the map on the Ambrosiana manuscript and the second place named Kyrenia is written with the same red ink as the epigram inside the map; therefore, one wonders if those place-names had escaped the attention of the copyist or if there was no reason for him to copy them. Furthermore, the note above the map referred to the previous manuscript and its removal is reasonable. At the same time, the anonymous copyist added a title above the map:

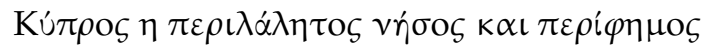

"Cyprus, the so famous and so celebrated island". (The transcription and translation are of Cronier and Gautier Dalché 2017, p. 180) 


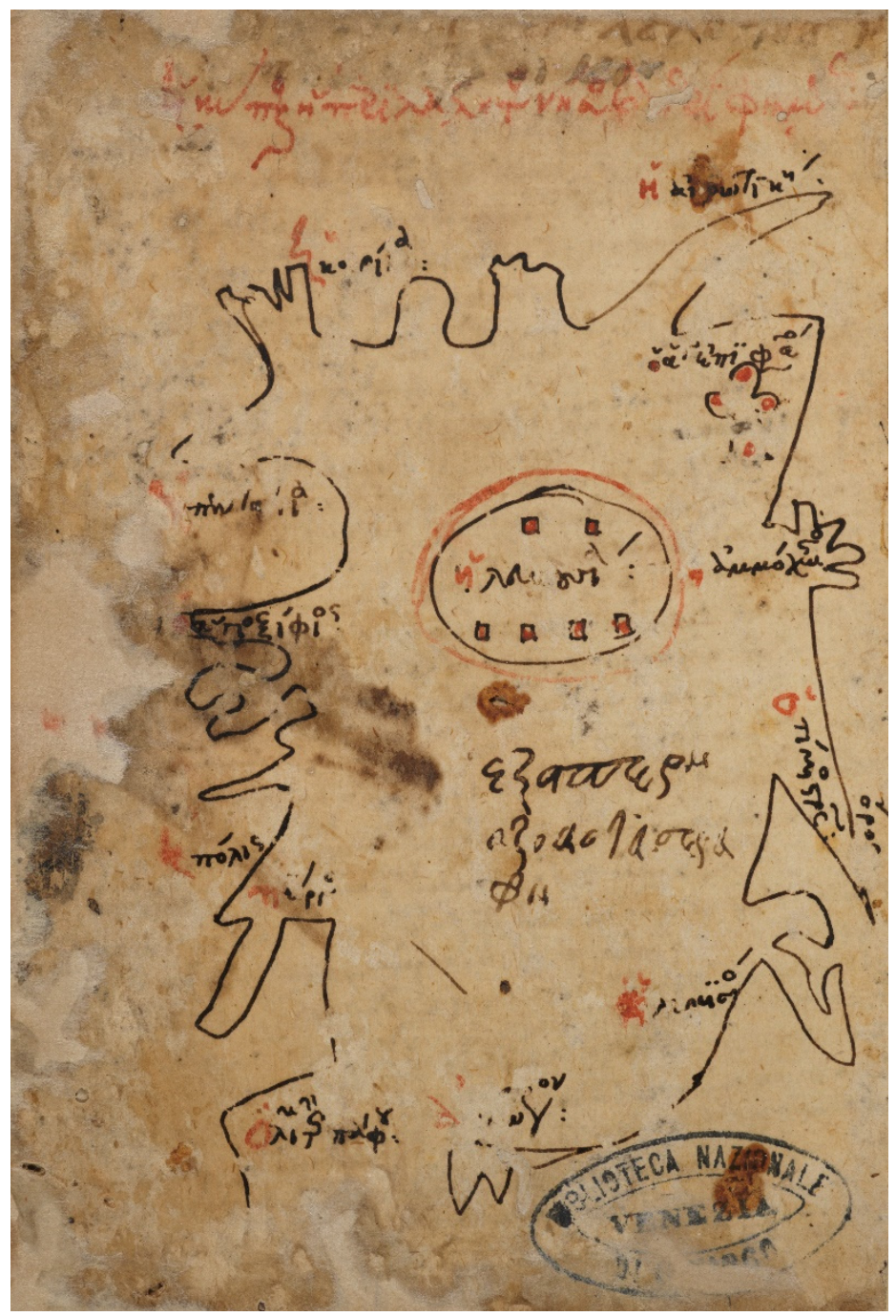

Figure 3. The Marciana map of Cyprus. Venice, Biblioteca Nazionale Marciana, gr. XI.21, f. 166v. Midfourteenth century (Reproduced with permission from the Biblioteca Nazionale Marciana, Venice).

The insertion of the title in the above map makes clear that the copyist intended to celebrate and glorify the island, probably his island. He erased the note from the initial manuscript (Ambrosiana manuscript) that labelled Cyprus as " $\pi \alpha v \alpha \theta \lambda i \alpha$ " (very

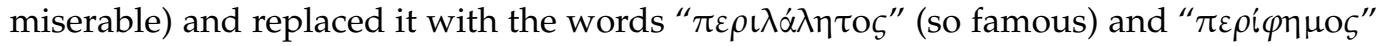
(so celebrated).

We suppose that the Marciana manuscript must have been copied at the monastery of Kykkos, as the monastery preserved a scriptorium during the Middle Ages (Yakovlevich 2010). According to the manuscript of Timios Stavros n.111 preserved at the Library of the Patriarch of Jerusalem, the monk Symeon completed the copying of a Psalter at Kykkos monastery in 1472, while the expenses were covered by the priest, Basil Chamados, who was the donor of the church of Archangelos Michail at Pedoulas (Perdikis 2014, p. 73). The speed at which the Ambrosiana's book was copied is remarkable. As a book with medical content, it was perhaps a greatly desired book and was, therefore, immediately copied. On the other hand, it may have been an order.

\section{Navigation and Maritime Pilgrimage Shrines}

The two maps discussed, especially the Ambrosiana map, link them not only to the theme of travel, but also of pilgrimage. The Ambrosiana map is not a record of a journey but instead reflects a more broadly shared sense of Cyprus as a destination. The paths 
of navigation are also paths of pilgrimage, as each of the coastal toponyms cited in the map has a maritime shrine linked to the sea, sailors, pilgrims, and the sea itineraries of the late Middle Ages. These shrines served various physical and spiritual needs. Maritime shrines were developed during the fourteenth and fifteenth centuries, not just in the Eastern Mediterranean generally, but more specifically in Cyprus due to the increase in sea exchanges, both in trade and in pilgrimage journeys (cf. Bacci 2014). Hence, the map is a valuable witness to pilgrimage in Cyprus and, thus, the movement illustrated by navigational maps does not simply respond to already-extant pilgrimage shrines, but also stimulates the development of new ones, reflecting the diversity of travellers who came with the sea. The frequent visits of travellers (traders, sailors, pilgrims, etc.) led to the need to shape the sites in ways that could serve the needs of travellers, especially pilgrims. Famagusta's case reflects this situation.

In particular, Famagusta had special importance during the late Middle Ages. It was an important trading centre, a cosmopolitan city which conserved a significant number of shrines in its territory (cf. Borowski 2018, pp. 70-73; Walsh 2019, pp. 2-8). The historian, Stefano Lusignan, rightly described the spirit of multiculturalism and population, the so-called mélange of different languages and religions that prevailed in Famagusta in the second half of the sixteenth century (Lusignano 1573, ff. 34r-35r; De Lusignan 1580, ff. 71r-76r). The city's population increased rapidly at the end of the thirteenth century, when Christian refugees from the East sought protection in Famagusta after the Muslim conquest of these areas (Jacoby 2014, pp. 53-67). The description of the Augustinian monk James of Verona, who arrived in Cyprus on 29 May 1335 and stayed for twenty days, constitutes one of the earliest testimonies of the arrival of refugees in Famagusta (Cobham 1908, p. 17). He reports the arrival at the city's port in June 1335 of fifteen thousand refugees (old people, women, and children) from Logaze in Armenia, which had been looted by the Ottomans. Indeed, Famagusta's population included not only Latins and Greeks but also Armenians and Syrian Christians, including communities of Melkites, Maronites, Jacobites and Nestorians (cf. Schabel 2005, passim).

Famagusta's port was transformed from a regional port into the major trading harbour of the period, making the city a real crossroads for trade between the East, West and Africa (cf. Coureas 2017). Undoubtedly, ports are hubs of communication, and they are connected by a network of maritime routes (Preiser-Kapeller 2015b, p. 125; Preiser-Kapeller and Werther 2018, p. 11). The dynamic of this connectivity emerges from the interactions and connections between individuals, groups, or sites (Preiser-Kapeller 2015a, p. 13). After 1291 Famagusta surpassed Limassol and became the island's main commercial city; the harbours of Paphos, Larnaca and Kyrenia were still in use as smaller ports. Together with Alexandria and Laiazzo, Famagusta's port was one of the three great emporia of the Eastern Mediterranean. Emmanuel Piloti, a Venetian merchant based in Crete, in 1420 reported that in the port of Famagusta merchants and goods from all over the Christian West could be found (Dopp 1958, p. 312). However, it is generally accepted that before the fourteenth century, the international sea traffic passed mainly along the southern cost of Cyprus and that Limassol constituted the island's main port (Nicolaou-Konnari and Schabel 2015, pp. 210-16).

Besides the Stavrovouni Monastery which is marked on the map, another important shrine for sailors and pilgrims in the fourteenth century and onwards was the underground chapel of St. Mary of the Cave (known as Santa Maria della Cava) or "Panagia Chrysospiliotissa" in Greek (cf. Papageorghiou 2010, pp. 57-58; Bacci 2019; Foulias 2021, pp. 692-94). The chapel is located to the north of the walled city close to the Torre dell'Oca, in Kato Varoshia in the neighbour of Spiliotissa or Chrysospiliotissa. The toponym "Spiliotissa" is recorded for the first time in the account of Danish traveller Cornelis de Bruyn (1683), who stopped in Cyprus after his trip to Alexandria (Cobham 1908, pp. 236-37; Bacci 2019, p. 54).

The site was an underground tomb dating to the Hellenistic period, which was probably transformed into a church somewhere before 1300, as the church is cited in two wills of Genoese merchants (Bacci 2019, p. 52). According to a Czech pilgrim, Oldřich 
Prefát (1546), the site was underground and was not visible from the outside (Prefát z Vlakanov 2014, p. 331; Bacci 2019, p. 65). The pilgrims descended a staircase of thirty-six steps which ended in a small room used probably as a narthex. The interior of the church was decorated with wall-paintings, wax offerings, candles, and small icons. James of Verona (1335) informs us that he and the ship's crew went to the underground shrine to give ex-votos offering (tamata) as thanksgiving for their deliverance from dangers (Cobham 1908, p. 16; Bacci 2019, pp. 50-51). It was a "shared" cult space as the architecture and the travellers' testimonies proved (Cobham 1908, p. 24; Bacci 2019, p. 52). Two large niche altars were carved on the east wall (Figure 4). The northern niche was covered by a $\Pi$-shaped iconostasis which separated the naos from bema and was used by Greeks. To either side of it, two smaller niches were carved on the wall and would be used as prothesis and diakonikon. The southern ogee arch remained uncovered and visible from the naos; it was probably used by Roman Catholics for serving the liturgy. The Latin presence at the church was also documented, at least from 1300, in two wills of merchants from Genoa mentioned above.

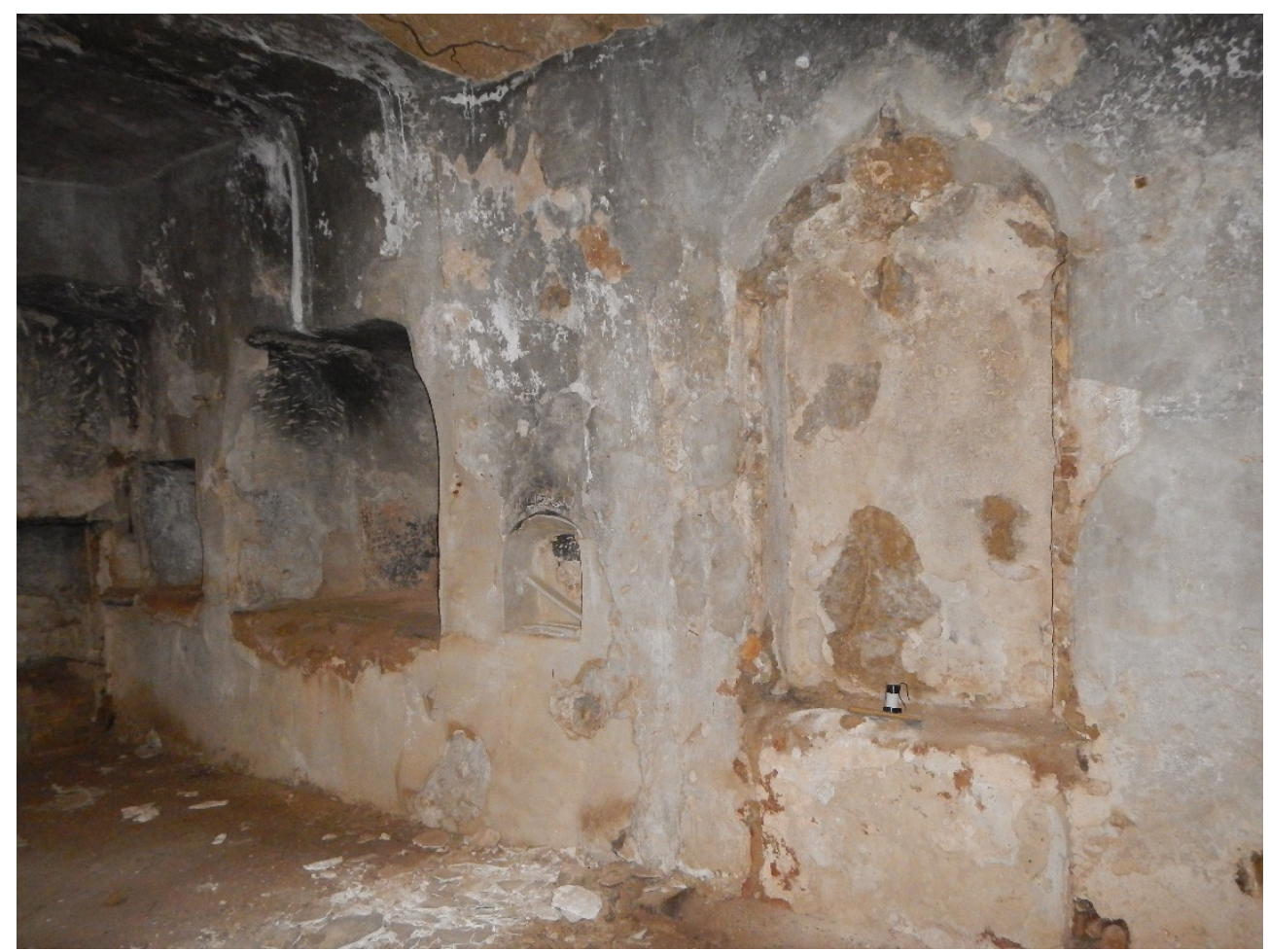

Figure 4. View of the east wall, St. Mary of the Cave, Famagusta (Photo: Andreas Foulias).

From 1328, St. Mary of the Cave was under the jurisdiction of the orthodox monks of the monastery of St. Catherine on Mount Sinai (Coureas 2010, pp. 471-72). Cyprus had close relations with the monastery of Mt. Sinai; besides St. Mary of the Cave, Sinai Monastery had also under its jurisdiction the pilgrimage of St. Catherine in Famagusta (cf. Calvelli 2014, pp. 372-76). At the end of the fourteenth century, a considerable European interest about the sacred topography and the pilgrimages dedicated to St. Catherine had emerged (Bacci 2016, pp. 331-32). The St. Catherine pilgrimage route, which passed through at least four holy sites associated with episodes of the saint's life (place of birth within the ruins of the basilica of Agios Epiphanios; the spot where she learned to read was within the Franciscan church; the site on which an angel "betrothed" Catherine to Christ located at the rocky islet near the harbour; and, her tomb at the area of Salamis) included also a visit to St. Mary of the Cave (Calvelli 2014; Borowski 2018, pp. 76-83). Many pilgrims devoted almost an entire day to visit the sites and get to know the life of St. Catherine in Famagusta. Then, they went to Alexandria and visited the Monastery of 
Sinai to venerate her relics (Bacci 2016, pp. 331-32, 335-36). However, after the Ottoman conquest of Egypt (1517), the journey to Sinai became dangerous and less and less pilgrims attempted it. Therefore, many pilgrims were content with the monuments of St. Catherine in Famagusta, which gained special fame in the sixteenth century. Certainly, the association of St. Catherine with Cyprus and the creation of the pilgrimage route had mainly economic goals.

Returning to St. Mary of the Cave, we do not know if some special holy object housed in the shrine helped to make it so popular and attract so many people. Nothing specific is mentioned in the shrine's visitors' detailed descriptions. Only in 1683, Cornelis de Bruyn noticed the existence of holy water/hagiasma in the naos of the church (Cobham 1908, p. 237; Bacci 2019, p. 54). Nevertheless, the Marian shrine may have had a miraculous icon in the late fourteenth and fifteenth century. It is worth mentioning that the central niche behind the iconostasis was decorated with the standing Virgin Mary, a location which indicates the special honour attributed to her; a rare but not unique position for the depiction of Virgin Mary (Bacci 2019, pp. 57-58). A parallel placement for Virgin Mary's portrait appeared in the church of Virgin Chryseleousa in Lysos, where a depiction of Virgin Mary Kykkotissa (fifteenth century) is placed in the niche of the sanctuary (Hadjichristodoulou and Foulias 2017, pp. 38-42). Annemarie Weyl Carr has suggested a comparison with the placement of the miracle-working icon of the Virgin Saidnaya near Damascus in Syria (Carr 1995, p. 350).

The association of St. Mary of the Cave with the sea and sailors is also indicated by its inclusion in the text of the procession of Sante Parole or Santa Parola dated to the second half of the fourteenth century (Bacci 2004, pp. 242-48; Ruzzin 2013, pp. 48-52; a catalogue with all the 130 pilgrimage sites invoked in Sante Parole is published by Bacci 2019, pp. 350-53). The above-mentioned procession took place on the ship shortly before sunset. The invocation could be modified and adjusted according to the location and the navigation of the ship, since it was made to allow sailors to pass safely from a specific sea area. According to James of Verona (1335) when the ship was off the Cypriot coast, the prayer included the underground chapel of Famagusta and the monastery of Stavrovouni (Cobham 1908, p. 16).

Another underground pilgrimage site associated with the sea, located not far from St. Mary of the Cave and northeast of the Martinengo Bastion, is dedicated to the protomartyr St. Thecla. According to Epiphanios of Salamis, the saint had a special place in the Christian world as she was considered second in status after the Virgin Mary (Panarior 79.5; Davis 2001, p. 74). The site was initially a Hellenistic tomb with dromos, and it was transformed into a church probably during the fourteenth century (Mogabgab 1951, p. 186; Bacci 2019, pp. 60-64; Foulias 2021, pp. 688-89). It was a "shared" worship place between Greeks and Latins. The presence of a shallow niche which ends in a tower-like crown is very close to the Eucharistic tabernacle used in Northern Europe during the late Middle Ages and it may indicate a possible association with Latin liturgy (Bacci 2019, p. 62; Figure 5). The interior walls of the shrine were decorated with coats of arms and geometric elements formed similar to a tapestry; some fragments are still visible. St. Thecla was a popular pilgrimage place due to the healing holy water, which was located in the middle of the main church, and which had the power to heal sick people trembling with fever (Bacci 2019, pp. 63-64). Possibly, many other small shrines existed in Famagusta and were correlated with the sea routes of the period. Based on Martoni's description (1394), ruined villages and cave churches existed in the area outside the west walls of the city (Cobham 1908, p. 24; cf. Foulias 2021, pp. 683-97). The transformation of ancient underground tombs into chapels that can be observed in the fourteenth century may be related with the increased number of pilgrims arriving in Famagusta during the late Middle Ages. 


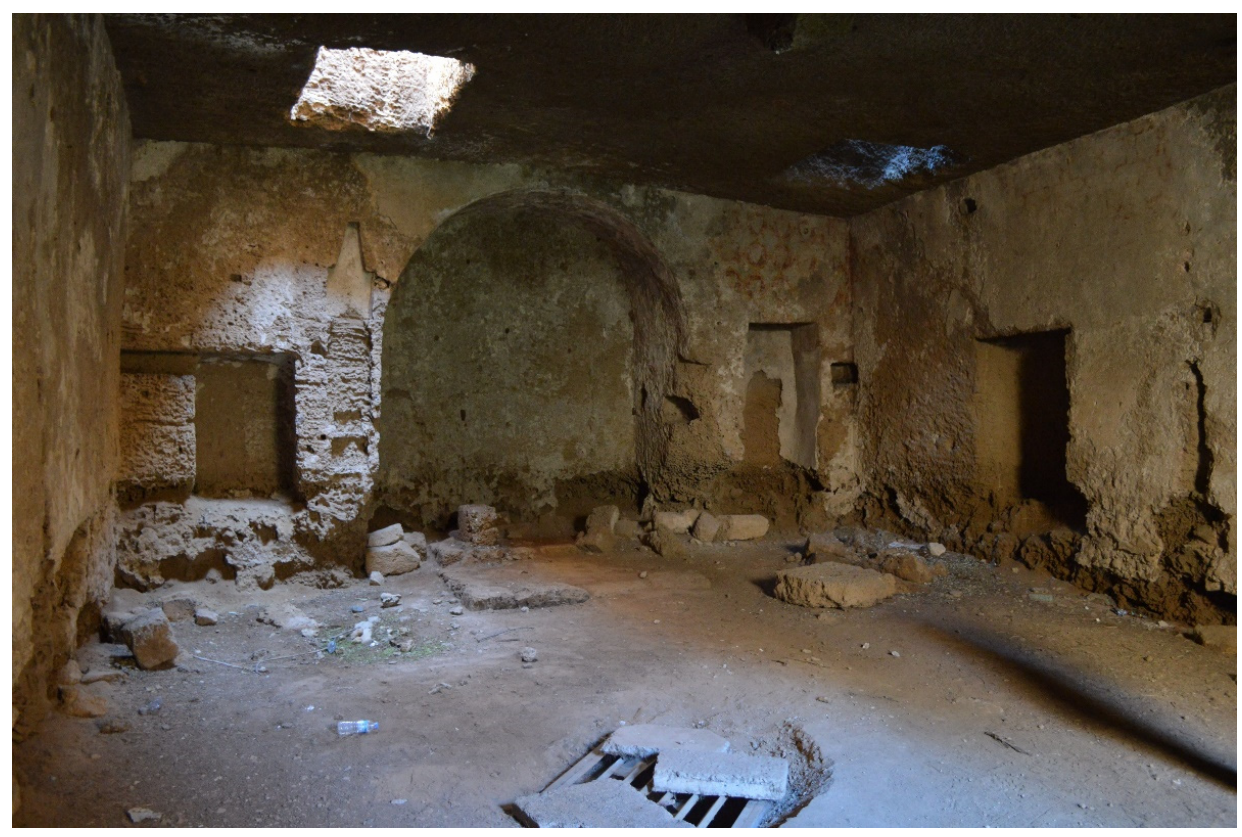

Figure 5. View of the interior, St. Thecla, Famagusta (Photo: Andreas Foulias).

Another case is the underground chapel of Agia Napa, located in the wider area of Famagusta, which became a popular pilgrimage destination due to its miraculous icon of the Virgin and its hagiasma, especially in the sixteenth century (Bacci 2009, pp. 44344; Petras 2019, pp. 145-65; Ritter 2019, pp. 125-44). It was also a "shared" cult place for Greeks and Latins. Oldřich Prefát, who visited the church on 2 October 1546, noted that there were Greek Orthodox and Roman Catholics, who worshipped separately (Prefát z Vlakanov 2014, §71, pp. 326-32; for English translation: Ritter 2019, pp. 143-44). The pilgrim's description provides the earliest preserved and most detailed reference for the pilgrimage site. The pilgrimage consisted of the underground cave where the icon was found miraculously. The cave was transformed into a church and a stone $\Gamma$-shape iconostasis dated to the fourteenth century separated the sanctuary from the naos (Petras 2019, pp. 150-55, 432, pl.5). The miraculous icon was situated at the right side of the iconostasis and was illuminated directly by sunlight. The holy water was located at the northern end of the cave. Over the centuries, various buildings were erected around the cave: a barrel-vaulted chapel, the so-called "Latin" (fourteenth-fifteenth century); annexes and, thus, a monastery was developed. According to recent archaeological excavations, the monastery seems to have been founded in the fourteenth century (Christofi 2020, p. 27). The pilgrims descended into the cave, where they obtained holy water/hagiasmsa and they then proceeded to the icon and, finally, if they wished, they participated in the Liturgy. The singular shape of the iconostasis gave visibility and access to the holy water and to the small opening where, according to tradition, the icon was found. The church was full of ex-votos such as ostrich eggs, wooden effigies of maritime ships and small icons (Ritter 2019, p. 144). The icon is only known by descriptions; it may have been stolen or destroyed by fire in the early nineteenth century. As Prefát noted, the icon had the height of a man and depicted the Virgin holding the Child. The figures' hands were covered with silver plating plaques, while their halos had gilded plaques decorated with precious stones. The German pilgrim, Hans Johann of Hürnheim, who visited Agia Napa on 15 August 1569, noted that the icon was painted by the apostle Luke (Ritter 2019, p. 125). Stefano Lusignan (sixteenth century) included the icon in his catalogue of the island's most venerated icons and noted that the icon was processed to Nicosia in times of high drought (De Lusignan 1580, f. 64r). Apparently, the icon was directly related to water, rain and, consequently, fertility, life, similar to another miraculous icon; that of Virgin Kykkotissa in the Troodos mountains. 
The Agia Napa shrine has been also associated with sailors and maritime trade routes of the late Middle Ages due to its proximity to the sea; the existence of a spring/holy water and a miraculous icon attracted seamen (cf. Petras 2019, pp. 145-47). The toponym appeared for the first time in 1538 in Matheo Pagano's map as "Sancta Napa"; it is cited as a monastery in Attar's map (1542) (Stylianou and Stylianou 1980, pp. 16-17; Cavazzana and Grivaud 2006, p. 136). Moreover, the toponym "Agia Napa" is already cited twice by Leontios Makhairas (fifteenth century). Specifically, in 1366, one year after the "Alexandrian Crusade" (1365), the King of Cyprus, Peter I (1359-69), wrote a letter to the Pope and gave it to the admiral, who sailed from Famagusta and then to Agia Napa (Dawkins 1932, $\S 174)$. Secondly, the toponym was attested during the destruction of Genoese ships, which were found at 'Agia Napa' bay in 1372 (Dawkins 1932, §549). However, Agia Napa is not mentioned as a stop for merchants and sailors approaching Famagusta's harbour. The sailors, usually, stopped at Pyla's cape, known as Cape Agios Georgios in medieval times, before arriving at Cape Greco (Delatte 1947, pp. 124-26).

The pilgrimage of Apostolos Andreas to the homonymous promontory in the Karpas peninsula, which flourished in the fifteenth-sixteenth century, can be inscribed in the same context of maritime pilgrimages (Bacci 2014, pp. 11-12). The initial core of the cult was the underground cave, which was directly connected with fresh water (cf. Foulias 2020, pp. 71-102). According to local tradition, Apostolos Andreas visited the area on his way to Palestine and miraculously created a sacred spring in the dry rock. Later, the captain of the ship, whose son was cured of blindness by the spring, is said to have built a church at the site. However, this tradition is not observed in the medieval sources. Recent archaeological excavations (2018) have shown that the cult of Apostolos Andreas goes back between the fourth and seventh century (Nicolaou, forthcoming). Based on written sources, the church seems to have existed at least since the end of the twelfth century (Foulias 2020, p. 74). During the fifteenth century, a twin-naved Gothic chapel was erected, reflecting the development of the pilgrimage. It is true that the cape of Apostolos Andreas was a passage from the dangerous cape of Antalya to the quiet and safe Levantine Sea, arriving to the port of Famagusta. In the late Middle Ages, sailors stopped at the Apostolos Andreas to take advantage of the clear spring water, offer their ex-votos and then pray. Afterwards, they continued their trip safely and protectively. It was a common practice to name promontories, which were dangerous and difficult to navigate through, after saints as well, as to construct religious edifies dedicated to the said saint (Bacci 2014, p. 11).

The pilgrimage of Apostolos Andreas seems to have been used for only a small period, as it seems to have been abandoned in the mid-sixteenth century. The Venetian nobleman Leonardo Donà who visited the monastery between 1556 and 1558, mentioned that it was abandoned (Patapiou 2006, p. 225; Foulias 2020, p. 76). Moreover, the Ottoman settlement of 1572, which recorded the Greek monasteries in the area, does not mention the monastery of Apostolos Andreas (Foulias 2020, pp. 98-99).

Another well-known pilgrimage site at the Akrotiri peninsula was the Monastery of Agios Nikolaos ton Gaton (St. Nicholas of the Cats). Its founding is also linked with St. Helen when she visited Cyprus in the fourth century. Stefano Lusignan in his Description (1580) wrote that Agios Nikolaos was a late antique foundation and linked it to Calocaerus, Duke of Cyprus, which attested in early sources but not in relation the monastery (De Lusignan 1580, ff. 18r-19v). The dedication of the monastery to Agios Nikolaos is first recorded in an eleventh century Cypriot manuscript (Constantinides and Browning 1993, pp. 66-67). Moreover, the monastery is also attested in the Historia ecclesiastica of the Benedictine chronicler Orderic Vitalis (1075-1142) (Papacostas 2015, p. 167). The actual church can be dated to the Lusignan period; thirteenth and fourteenth centuries, with fifteenth century reconstructions. However, spolia from early Christian period are still visible in the church (Papacostas 2015, pp. 167-68; Olympios 2015, pp. 423-24).

The monastery was very popular among sailors and pilgrims, especially in the late medieval period. Its main attraction was the great number of cats that the monks kept in order to hunt and kill the snakes that infested the Akrotiri peninsula. According to 
pilgrims' testimonies, which seem excessive, the cats' number was between two hundred and one thousand during the fourteenth century (Cobham 1908, pp. 37, 38; Grivaud 1990, pp. 117-18). The importance of cats in killing snakes in order to make the place habitable is declared by the fact that King James II (1463-73) had provided the monastery with three hundred and fifty ducats annually for the cats' care (Nicolaou-Konnari and Schabel 2015, pp. 318-19). Cats, and the great number of pilgrims visited the site, especially in order to see them, gave the monastery large revenues (Cobham 1908, p. 48). Finally, the monastery may have preserved an hagiasma; however, because of the large number of cats which was the most impressive attraction, the holy water is not mentioned in pilgrims' accounts.

An important landmark was the church of Agios Lazaros in Larnaca (Salines), housing the tomb of St. Lazaros, the first bishop of Kition. According to tradition and to archaeological evidence, the church was erected by Leon VI, called the Wise (886-912), at the end of the ninth and at the beginning of the tenth century. Even after the translation of the precious relics in Constantinople, the church was rebuilt and repaired over the centuries (cf. Papageorghiou 1998). The church was located near the port of Larnaca, another important port of the Eastern Mediterranean basin, which was an economic centre where the salt lakes of Larnaca yielded rich deposits of salt and their revenues were lucrative enough for the extraction and sale of salt (Coureas 2005, pp. 105, 108). In the late fifteenth century, the northern aisle of the church was converted into a "Latin chapel" dedicated to the Virgin Mary. Due to the increasing number of pilgrims, the installation of a Latin clergy within a Greek church was considered necessary in order to service the foreign pilgrims who came to the church (Olympios 2013, pp. 326-28). This is a common practice observed in shrines located near harbours. In this framework, Prefát's remark can be noted (1546); when he visited the monastery of Agia Napa, he met an Augustinian monk who lived there (Prefát z Vlakanov 2014, pp. 326-32, §71; Ritter 2019, pp. 143-44). We suppose that the presence of an Augustinian monk servicing the needs of Latin pilgrims who visited the shrine does not necessarily mean the installation of the Order at the monastery.

\section{Concluding Remarks}

This article has aimed to examine the connectivity of Cyprus as a focal point of movement, sometimes more intense, sometimes more restricted, during the late Middle Ages. Through this navigation, a number of pilgrimage sites were developed, reflecting the diversity of travellers who came to the island.

The unique freehand map of Cyprus preserved on a medical manuscript was created by an unknown "cosmopolitan" man. The history of the manuscript and its owner is quite interesting, as this man seemed to have a varied career and relationships. The map indicates the maritime centres of the island, which constituted religious and economic centres of the late Middle Ages. It seems to be copied; the owner of the manuscript at that time is not the creator of this map. It is more plausibly a nautical map which gave sailing information. Its importance lies in the fact that, for the first time, the sea voyage and maritime routes which had Cyprus as a stopover during the late Middle Ages, are captured. Moreover, it gives precious information about the coastal line of the island, the holy names, and the toponyms. Needless to say, this map comprises a unique document and offers novel insights into fourteenth century Cyprus. We hope that future research may bring to light more information about these two maps and manuscripts in general.

It is unsurprising that from the fourteenth century onwards, the increase in mobility for trade or/and pilgrimage reasons in the Eastern Mediterranean basin developed the island as a major stopover, which was accompanied by the establishment of a network of new shrines associated with the maritime itineraries. This connectivity is also expressed through a pre-modern series of ship graffiti, dated from the sixteenth century and preserved in churches mainly located in the areas between Famagusta and Larnaca; it has been suggested that they were executed by travellers who wished to disembark and visit shrines which were located on routes that connected the two major ports of the island (Walsh 2007; Michael 2015; Demesticha et al. 2017). The loca sancta discussed in the article were linked directly 
or indirectly with water, which was a precious liquid for ships' supplies and also a precious and holy liquid (hagiasma) for religious practices. The majority of maritime pilgrimage sites preserved this miraculous-therapeutic holy water (hagiasma) and provided their visitors with fresh water which was important for their physical survival. Furthermore, most of the coastal shrines were venerated by more than one religious community (Greek, Latins, other denominations of Christianity). The phenomenon of "mixed" or "shared" shrines is not only observable in Cyprus; it is a well-established phenomenon in the Mediterranean area where different religious groups have lived from the medieval past to modern times (cf. Alberta 2012; Couroucli 2014). The presence of different religious groups in the same shrine did not mean that there is no religious or cultural diversity between them. Moreover, the "establishment" of Latin orders in Greek churches, located mainly near coast and ports, may be interpreted in the context of better service and economic exploitation of the Latin pilgrims/travellers. It is difficult to assess the exact role of these maritime shrines within the island. Undoubtedly, they served as a source of revenue and benefited the whole surrounding area, not only from donations but also because of the many people attracted by the shrine. This category of shrines, referred to as "maritime" pilgrimage sites, is clearly related with seamen and it is distinguished from other Cypriot sacred sites located mainly inland. Their connection to the sea routes and sailors gives them a more cosmopolitan air, removes them partly from their local dimension, and integrates them into a wide network of maritime communication.

Funding: This article is part of the research project "The Spatiality and Materiality of Pilgrimage in Byzantine and Medieval Cyprus and Religious Networks in the Eastern Mediterranean (11th-16th century) - SpaMaP Cy" (Restart 2016-20, DIDAKTOR, POST-DOC/0916/0251), co-funded by the European Regional Development Fund and the Republic of Cyprus, through the Cyprus Research and Innovation Foundation, and hosted by the Archaeological Research Unit, University of Cyprus.

Institutional Review Board Statement: Not applicable.

Informed Consent Statement: Not applicable.

Data Availability Statement: Not applicable.

Acknowledgments: I wish to extend my special thanks to the editors and reviewers for their comments and suggestions. Many thanks also go to Annemarie Weyl Carr, Andreas Foulias and Stylianos Perdikis for their valuable help.

Conflicts of Interest: The author declares no conflict of interest. The funders had no role in the design of the study; in the collection, analyses, or interpretation of data; in the writing of the manuscript, or in the decision to publish the results.

\section{References}

Alberta, Dionigi. 2012. Crossing the Frontiers between the Monotheistic Religions, an Anthropological Approach. In Sharing Sacred Spaces in the Mediterranean. Christians, Muslims, and Jews and Shrines and Sanctuaries. Edited by Dionigi Albera and Maria Couroucli. Bloomington and Indianapolis: Indiana University Press, pp. 219-44.

Bacci, Michele. 2004. Portolano Sacro. Santuari e immagini sacre lungo le rotte di navigazione del Mediterraneo tra tardo Mediovo e prima età moderna. In The Miraculous Image in the Middle Ages and Renaissance. Edited by Erik Thuno and Gerhard Wolf. Rome: L'Erma di Bretschneider, pp. 223-48.

Bacci, Michele. 2009. Mixed' Shrines in Late Byzantine Period. In Archaeologia Abrahamica. Studies in Archaeology and Artistic Tradition of Judaism, Christianity and Islam. Edited by Leonid Beliaev. Moscow: Russian Academy of Sciences Institute of Archeology, pp. 433-44.

Bacci, Michele. 2014. On the Topography of Sailors: An Introduction. In The Holy Portolano. The Sacred Geography of Navigation in the Middle Ages. Edited by Michele Bacci and Martin Rohde. Berlin, Munich and Boston: De Gruyter, pp. 7-16.

Bacci, Michele. 2016. Shaping the Holy Topography of Saint Catherine in the Late Middle Ages. In At Home in Art: Essays in Honor of Mario Buhagiar. Edited by Charlene Vella. Malta: Midsea Books, pp. 3325-88.

Bacci, Michele. 2019. A Holy Site for Sailor: Our Lady of the Cave in Famagusta. In Famagusta Maritima. Mariners, Merchants, Pilgrims and Mercenaries. Edited by Michael J. K. Walsh. Leiden and Boston: Brill, pp. 43-71.

Balard, Michel. 1993. Mercanti-viaggiatori a Cipro nel Quattrocento. In Relazioni di viaggio e conoscenza del mondo fra Medioevo e Umanesimo: Atti del 5. convegno internazionale di studi dell'Associazione per il Medioevo e l'Umanesimo Latini (AMUL), Genova, 12-15 dicembre 1991. Edited by Stefano Pittaluga. Genova: Università di Genova, pp. 271-82. 
Borowski, Tomasz. 2018. Religion and Conflict: Investigating the Role of Relics and Holy Sites in the Religiously Diverse Society of Crusader Famagusta, Cyprus. In Crusading in Art, Thought and Will. Edited by Matthew E. Parker, Ben Halliburton and Anne Romine. Leiden and Boston: Brill, pp. 68-109.

Burkiewicz, Łukasz. 2018. Cyprus est terra Christianorum ultima. Wielokulturowy Cypr w oczach Polaków pielgrzymujących do Ziemi Świętej (do 1878 roku). In Terra culturae. Obszary, transfery, recepcje kultury. Studia oraz szkice o kulturze i historii. Edited by Łukasz Burkiewicz. Krakow: Wydawnictwo Akademii Ignatianum w Krakowie, Wydawnictwo WAM, pp. $209-44$.

Calvelli, Lorenzo. 2009. Cipro e la memoria dell'Antico fra Medioevo e Rinascimento. La percezione del passato romano dell'isola nel mondo occidentale. Venice: Istituto Veneto di Scienze, Lettere ed Art.

Calvelli, Lorenzo. 2014. Cypriot origins, Constantinian blood: The legend of the young Saint Catherine of Alexandria. In Identity/Identities in Late Medieval Cyprus; Edited by Tassos Papacostas and Guillaume Saint-Guillain. Nicosia: Cyprus Research Centre, pp. 361-90.

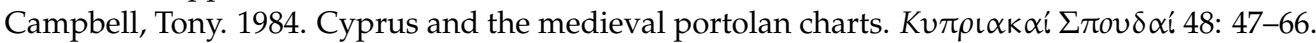

Carr, Annemarie Weyl. 1995. Byzantines and Italians on Cyprus: Images from Art. Dumbarton Oaks Papers 49: 239-74. [CrossRef]

Cavazzana, Francesca Romanelli, and Gilles Grivaud. 2006. Cyprus 1542. The Great Map of the Island by Leonida Attar. Nicosia: Bank of Cyprus Cultural Foundation.

Christofi, Polina. 2020. The Palimpsest under the Monument: Revisiting the Medieval Monastery of Ayia Napa in the Light of New Evidence. In Third International Conference on Byzantine and Medieval Studies, 17-19 January 2020. Abstracts of Presentations. Edited by Christina Kakkoura and Andreas Foulias. Nicosia: Keramos, p. 27.

Translated and Edited by Claude D. Cobham. 1908, Excerpta Cypria: Materials for a History of Cyprus. Cambridge: University Press.

Constantinides, Costas N., and Robert Browning. 1993. Dated Greek Manuscripts in Cyprus to the Year 1570; Washington, DC and Nicosia: Dumbarton Oaks Research Library and Collection and Cyprus Research Centre.

Coureas, Nicholas. 2005. Economy. In Cyprus: Society and Culture 1191-1374. Edited by Angel Nicolaou-Konnari and Chris Schabel. Leiden and Boston: Brill, pp. 129-56.

Coureas, Nicholas. 2010. The Latin Church in Cyprus, 1313-1378; Nicosia: Cyprus Research Centre.

Coureas, Nicholas. 2017. The Lusignan Kingdom of Cyprus and the Sea, 13th-15th centuries. In The Sea in History. The Medieval World. Edited by Christine Buchet and Michel Balard. Woodbridge: Boydell and Brewer, pp. 369-81.

Coureas, Nicholas, and Christopher Schabel, eds. 1997. The cartulary of the Cathedral of Holy Wisdom of Nicosia; Nicosia: Cyprus Research Centre.

Couroucli, Maria. 2014. Shared Sacred Places. In A Companion to Mediterranean History. Edited by Peregrine Horden and Sharon Kinoshita. Malden and Oxford: Wiley-Blackwell, pp. 378-91.

Cronier, Marie. 2020. Quelques manuscrits médicaux grecs liés à Chypre. In Griechisch-Byzantinische Handschriftenforschung. Traditionen, Entwicklungen, neue Wege. Edited by Christian Brockmann, Daniel Deckers, Dieter Harlfinger and Stefano Valente. Berlin and Boston: De Gruyter, pp. 131-43.

Cronier, Marie, and Patrick Gautier Dalché. 2017. A Map of Cyprus in Two Fourteenth-Century Byzantine Manuscripts. Imago Mundi 69: 176-87. [CrossRef]

Davis, Stephen J. 2001. The Cult of Saint Thecla: A Tradition of Women's Piety in Late Antiquity. Oxford: Oxford University Press.

Dawkins, Richard M., ed. 1932. Leontios, Makhairas, Recital Concerning the Sweet Land of Cyprus, Entitled 'Chronicle'. Oxford: Clarendon Presse, vol. I.

De Lusignan, Estienne. 1580. Description de toute l'isle de Chypre. repr. 2004. Paris: Guillaume Chaudiere, Nicosia: Cultural Foundation of the Bank of Cyprus.

Delatte, Armand. 1947. Les portulans grecs. Liege: Bibliothèque de la Faculté de Philosophie et des Lettres de l’Université de Liége.

Deligiannakis, Georgios. 2018a. The Last Pagans of Cyprus: Prolegomena to a History of Transition from Polytheism to Christianity. In Church Building in Cyprus (Fourth to Seventh Centuries). A Mirror of Intercultural Contacts in the Eastern Mediterranean. Edited by Marietta Horster, Doria Nicolaou and Sabine Rogge. Münster: Waxmann, pp. 23-44.

Deligiannakis, Georgios. 2018b. From Aphrodite(s) to Saintly Bishops in Late Antique Cyprus. In Authority and Identity in Emerging Christianities in Asia Minor and Greece. Edited by Cilliers Breytenbach and Julien M. Ogereau. Leiden and Boston: Brill, pp. 326-46.

Demesticha, Stella, Katerina Delouca, Mia Gaia Trentin, Nikolas Bakirtzis, and Antonis Neophytou. 2017. Seamen on Land? A Preliminary Analysis of Medieval Ship Graffiti on Cyprus. The International Journal of Nautical Archaeology 46: 346-81. [CrossRef]

Deycks, Ferdinand, ed. 1851. Ludolph von Sudheim, Ludolphi de itinere Terrae Sanctae liber (1335-1341). Stuttgart: Litteraricher Verein.

Dopp, Pierre-Herman, ed. 1958. Emmanuel Piloti, Traité d’Emmanuel Piloti sur le passage en Terre Sainte (1420). Louvain: Nauwelaerts.

Fejfer, Jane, ed. 1995. Ancient Akamas I. Settlement and Environment. Aarhus: Aarhus University Press.

Foulias, Andreas. 2019. The Basilica of Saint Epiphanios: Architecture and Chronology. In Salamis of Cyprus. History and Archaeology from the Earliest Times to Late Antiquity. Edited by Sabine Rogge, Christina Ioannou and Theodoros Mavrojannis. Münster: Waxmann, pp. 719-29.

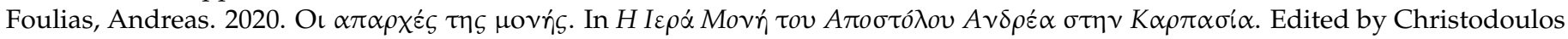
Hadjichristodoulou and Andreas Foulias. Nicosia: Holy Diocese of Karpasia, pp. 71-102.

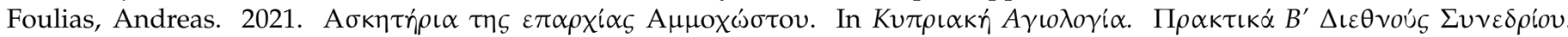

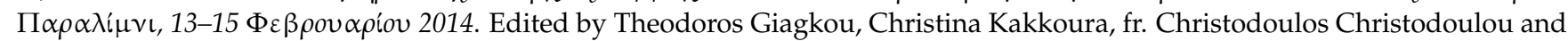
fr. Nikolaos Papantoniou. Agia Napa and Paralimni: Holy Diocese of Konstantia and Ammochostos, pp. 678-735. 
Garzaniti, Marcello, ed. 1991. Daniil Egumeno, Itinerario in Terra Santa. Rome: Città Nova Editrice.

Grivaud, Gilles, ed. 1990. Excerpta Cypria Nova. Volume Premier: Voyageurs occidentaux à Chypre au XVème Siècle; Nicosia: Cyprus Research Centre.

Grivaud, Gilles. 2008. A propos du manoir dans l'Orient latin: Le cas du royaume de Chypre (XIIIe-XVe siècle). In Des châteaux et des sources. Archéologie et histoire dans la Normandie médiévale. Edited by Jean-Louis Roch, Bruno Lepeuple and Elisabeth Lalou. Mont-Saint-Aignan: Presses universitaire de Rouen et du Havre, pp. 353-74.

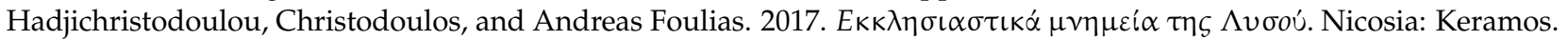

Hadjikyriakou, Antonis. 2017. Envisioning Insularity in the Ottoman World. Princeton Papers: Interdisciplinary Journal of Middle Eastern Studies 18: vii-xix.

Harvey, Paul D. A. 1991. Medieval Maps. London: The British Library.

Hoade, Eugene. 1970. Western Pilgrims. The Itineraries of Fr. Simon Fitzsimons (1322-23), a Certain Englishman (1344-45), Thomas Brygg (1392), and Notes on Other Authors and Pilgrims. Jerusalem: Franciscan Printing Press.

Jacoby, David. 2014. Refugees from Acre in Famagusta around 1300. In The Harbour of All this Sea and Realm. Crusader to Venetian Famagusta. Edited by Michael J. K. Walsh, Tamás Kiss and Nicholas S. H. Coureas. Budapest: Central European University Press, pp. 53-67.

Jacoby, David. 2016. Evolving routes of Western pilgrimage to the Holy Land, eleventh to fifteenth century: An overview. In Unterwegs im Namen der Religion II/On the Road in the Name of Religion II. Edited by Klaus Herbers and Hans Christian Lehner. Stuttgart: Franz Steiner, pp. 75-97.

Jeffrey, George. 1983. A Description of the Historic Monuments of Cyprus: Studies in the Archaeology and Architecture of the Island. London: Zeno Booksellers and Publishers.

Kaffenberger, Thomas. 2014. Harmonizing the Sources: An Insight into the Appearance of the Hagios Georgios Complex at Various Stage of its Building History. In The Harbour of All This Sea and Realm. Crusader to Venetian Famagusta. Edited by Michael J. K. Walsh, Tamás Kiss and Nicholas S. H. Coureas. Budapest: Central European University Press, pp. 169-90.

Lusignano, Steffano. 1573. Chorograffia. repr. 2004. Bologna: Alesandro Benaccio, Nicosia: Museum of the Holy Monastery of Kykkos. Mansouri, Mohamed Tahar. 2001. Chypre dans les sources arabes médiévales; Nicosia: Cyprus Research Centre.

Maraval, Pierre. 1985. Lieux saints et pèlerinages d'Orient. Histoire et géographie des origins à la conquête arabes. Paris: Cerf.

Maraval, Pierre. 1996. Récits des premiers pèlerins chrétiens au Proche-Orient (IVe-VIIe s.). Paris: Cerf.

Mas Latrie, Louis. 1970. Histoire de l'île de Chypre: Sous la règne des princes de la maison de Lusignan. Famagusta: Les éditions L'Oiseau, vol. III.

Megaw, Arthur H. S. 1974. Architecture and Decoration in Cyprus: Metropolitan or Provincial? Dumbarton Oaks Papers 28: 57-88. [CrossRef]

Michael, Maria. 2015. Ship graffiti in context: A preliminary study of Cypriot patterns. In Cypriot Cultural Details, Proceedings of the 10th Post Graduate Cypriot Archaeology Conference. Edited by Iosif Hadjikyriakos and Mia Gaia Trentin. Oxford and Philadelphia: Oxbow Books, pp. 41-64.

Mogabgab, Theophilus. 1951. Excavations and Researches in Famagusta, 1937-1939. Report of the Department of Antiquities Cyprus 1937-1939 181: 190.

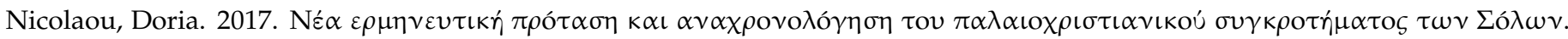
Deltion of the Christian Archaeological Society 38: 57-86.

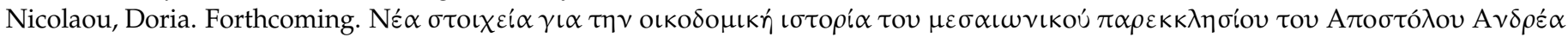

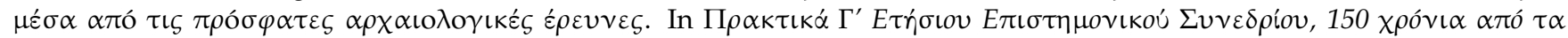

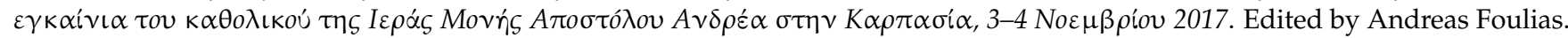
Nicosia: Theological School of Church of Cyprus.

Nicolaou-Konnari, Angel, and Chris Schabel. 2015. Limassol under Latin rule, 1191-1571. Lemesos. In A History of Limassol in Cyprus from Antiquity to the Ottoman Conquest. Edited by Angel Nicolaou-Konnari and Chris Schabel. Newcastle upon Tyne: Cambridge Scholars Publishing, pp. 195-361.

Olympios, Michalis. 2013. Shared Devotions: Non-Latin Responses to Latin Sainthood in Medieval Cyprus. Journal of Medieval History 39: 321-41. [CrossRef]

Olympios, Michalis. 2015. Rummaging through Ruins: Architecture in Limassol in the Lusignan and Venetian periods. In A History of Limassol in Cyprus from Antiquity to the Ottoman Conquest. Edited by Angel Nicolaou-Konnari and Chris Schabel. Newcastle upon Tyne: Cambridge Scholars Publishing, pp. 362-500.

Papacostas, Tassos. 2014. Byzantine Famagusta: An Oxymoron? In Famagusta. Volume I: Art and Architecture. Edited by Annemarie Weyl Carr. Turnhout: Brepols, pp. 25-61.

Papacostas, Tassos. 2015. Neapolis/Nemesos/Limassol: The rise of a Byzantine Settlement from Late Antiquity to the time of the Crusades. In A History of Limassol in Cyprus from Antiquity to the Ottoman Conquest. Edited by Angel Nicolaou-Konnari and Chris Schabel. Newcastle upon Tyne: Cambridge Scholars Publishing, pp. 96-188.

Papacostas, Tassos. 2018. Manuscript Notes and the Black Death in Rural Cyprus. In Reading in the Byzantine Empire and Beyond. Edited by Teresa Shawcross and Ida Toth. Cambridge: Cambridge University Press, pp. 133-55.

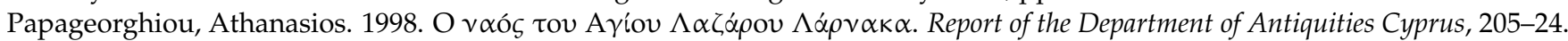




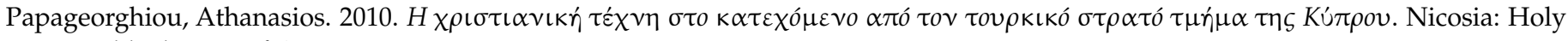
Archbishopric of Cyprus.

Papantoniou, Giorgos. 2012. Religions and Social Transformation in Cyprus. From the Cypriot Basileis to the Hellenistic Strategos. Leiden and Boston: Brill.

Papantoniou, Giorgos. 2016. Cypriot Ritual and Cult from the Bronze to the Iron Age: A longue-durée approach. Journal of Greek Archaeology 1: 73-108.

Patapiou, Nasa. 2006. Leonardo Donà, Memorie per le cose di Cipro: From the City of Shoal Waters to Outermost Karpasia. In "Sweet Land ... " Lectures on the History and Culture of Cyprus. Edited by Julian Chrysostomides and Charalambos Dendrinos. Camberley: Porphyrogenitus, pp. 206-30.

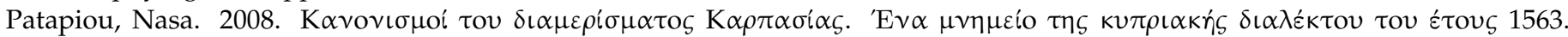

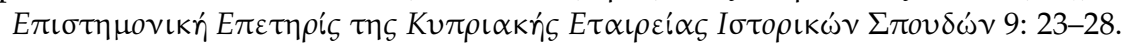

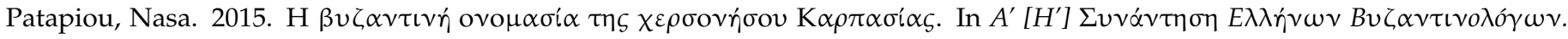

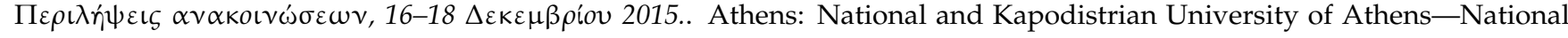
Hellenic Research Foundation, p. 66.

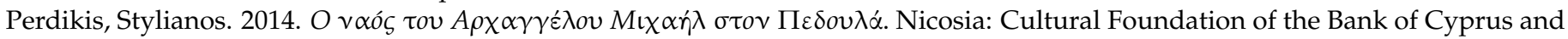
Holy Bishopric of Morphou.

Petras, Guido. 2019. A Stone Iconostasis in a Multi-Confessional Sanctuary in Lusignan and Venetian Cyprus? An Art-Historical Approach to the Cave Church in Agia Napa. In The Art and Archaeology of Lusignan and Venetian Cyprus (1192-1571). Edited by Michalis Olympios and Maria Parani. Turnhout: Brepols, pp. 145-68.

Prefát z Vlakanov, Oldřich. 2014. Cesta z prahy do benátek a odtud potom po moři až do palestyny. Prague: Mĕstská knihovna v Praze, Available online: http://web2.mlp.cz/koweb/00/04/06/10/86/cesta_z_prahy_do_benatek.pdf (accessed on 27 September 2021).

Preiser-Kapeller, Johannes. 2015a. Harbours and Maritime Networks as Complex Adaptive Systems-A Thematic Introduction. In Harbours and Maritime Networks as Complex Adaptive Systems. Edited by Johannes Preiser-Kapeller and Falko Daim. Mainz: Römisch-Germanisches Zentralmuseum, pp. 1-24.

Preiser-Kapeller, Johannes. 2015b. Harbours and Maritime Mobility: Networks and Entanglements. In Harbours and Maritime Networks as Complex Adaptive Systems. Edited by Johannes Preiser-Kapeller and Falko Daim. Mainz: Römisch-Germanisches Zentralmuseum, pp. 119-40.

Preiser-Kapeller, Johannes, and Lukas Werther. 2018. Connecting Harbours. A Comparison of Traffic Networks across Ancient and Medieval Europe. In Harbours as Objects of Interdisciplinary Research: Archaeology + History + Geosciences. Edited by Claus von Carnap-Bornheim, Falko Daim, Peter Ettel and Ursula Warnke. Mainz: Römisch-Germanisches Zentralmuseum, pp. 7-31.

Ritter, Max. 2019. Famagusta and its Environs in the Venetian period: The foundation of the monastery of Agia Napa and the origins of its fountain. In The Art and Archaeology of Lusignan and Venetian Cyprus (1192-1571). Edited by Michalis Olympios and Maria Parani. Turnhout: Brepols, pp. 125-44.

Roudometof, Victor, and Michalis N. Michael. 2010. Economic Functions of Monasticism in Cyprus: The Case of the Kykkos Monastery. Religions 1: 54-77. [CrossRef]

Ruzzin, Valentina. 2013. La Bonna Parolla. Il portolano sacro genovese. Atti della Società ligure di storia patria 53: 21-59.

Translated and Edited by Chris Schabel. 2001, The Synodicum Nicosiense and Other Documents of the Latin Church of Cyprus, 1196-1373; Nicosia: Cyprus Research Centre.

Schabel, Chris. 2005. Religion. In Cyprus: Society and Culture 1191-1374. Edited by Angel Nicolaou-Konnari and Chris Schabel. Leiden and Boston: Brill, pp. 157-218.

Janet Shirley, trans. 2001, Edbury, Peter W., ed. Guillaume de Machaut, Guillaume de Machaut: The capture of Alexandria. London and New York: Routledge.

Simsky, Andrew. 2020. The Discovery of Hierotopy. Journal of Visual Theology 1: 9-28.

Stylianou, Andreas, and Judith Stylianou. 1980. The History of the Cartography of Cyprus; Nicosia: Cyprus Research Centre.

Toumpouri, Marina. 2018. On the Commemorative Practices surrounding Pilgrimage: Some examples from Cyprus. Pilgrim Libraries: Books \& Reading on the Medieval Routes to Rome \& Jerusalem. A Leverhulme International Research Network. Principal Investigator: Professor Anthony Bale. Available online: http://www7.bbk.ac.uk/pilgrimlibraries/2018/02/16/toumpouri/ (accessed on 27 September 2021).

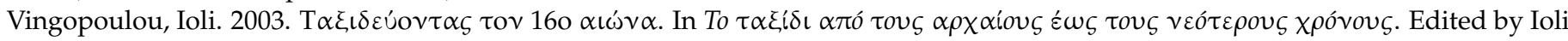
Vingopoulou. Athens: National Hellenic Research Foundation, pp. 137-68.

Vionis, Athanasios K., and Giorgos Papantoniou. 2019. Central Place Theory Reloaded and Revised: Political Economy and Landscape Dynamics in the Longue Durée. Land 8: 36. [CrossRef]

Wallace, Paul W. 1984. The Akamas Promontory of Cyprus. Report of the Department of Antiquities Cyprus, 341-47.

Walsh, Michael J. K. 2007. "On of the Princypalle Havenes of the See": The Port of Famagusta and the Ship Graffiti in the Church of St George of the Greeks, Cyprus. The International Journal of Nautical Archaeology 37: 1-15. [CrossRef]

Walsh, Michael J. K. 2019. Introduction: Old Ships [Sail] Like Swans Asleep ... for Famagusta and the Hidden Sun. In Famagusta Maritima. Mariners, Merchants, Pilgrims and Mercenaries. Edited by Michael J. K. Walsh. Leiden and Boston: Brill, pp. 1-42.

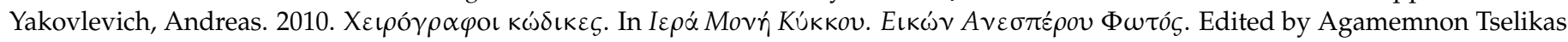
and Stylianos Perdikis. Athens: Cultural Foundation of the Holy Monastery of Kykkos, pp. 162-69. 